\title{
THE GENERAL EQUILIBRIUM MODEL OF BANK INDONESIA (GEMBI)
}

\author{
Charles Joseph, \\ Janu Dewandaru, Hidayah Dhini Ari ${ }^{*}$
}

\section{Pedahuluan}

ampai saat ini Bank Indonesia telah memiliki model makro ekonometrik yang cukup paripurna seperti MODBI. Model makro seperti MODBI tersebut bersifat statik dan sangat berguna bagi kepentingan proyeksi makro jangka pendek. Namun, berdasarkan beberapa alasan fundamental model ekonometrik tersebut secara teoritis tidak dapat dipakai sebagai alat penunjuk arah gerak dinamis dari berbagai variable makro jangka menengah dan panjang. Untuk itu suatu model makro yang dinamis (dynamic macro model) yang digenerate dengan data artifisial (artificial generated data) yang bersifat random telah dikembangkan dan diberi nama General Equilibrium Model of Bank Indonesia (GEMBI). ${ }^{1 \text { ) }}$

GEMBI merupakan suatu model ekonomi makro yang memiliki kemampuan untuk melakukan simulasi kebijakan moneter dan fiskal (policy simulation $\mathcal{E}$ analysis) dan analisa dampak kebijakan terhadap besaran-besaran ekonomi, serta menghasilkan lintasan dinamik (dynamic path) dari besaran-besaran makroekonomi seperti inflasi, suku bunga, nilai tukar nominal dan riil, PDB dan current account. Dalam operasionalnya, GEMBI akan dipergunakan secara bersama-sama dengan model ekonomi tahunan MODBI dan model ekonomi triwulanan MODBIQ untuk saling mendukung dan melengkapi.

Dalam kaitannya dengan Inflation Targeting framework (IT), GEMBI akan sangat bermanfaat dalam kegiatan simulasi jangka menengah-panjang dampak kebijakan moneter dan fiskal pada perkembangan laju inflasi (policy simulation). Misalnya, seberapa besar pengaruh perubahan money stock terhadap tekanan inflasi pada dua triwulan ke depan, bagaimana dampak kebijakan kenaikan government spending oleh pemerintah terhadap target inflasi tahunan, atau seberapa besar dampak suatu shock nilai tukar / depresiasi terhadap perkembangan inflasi dalam negeri. Adanya lag dari suatu kebijakan dengan efeknya pada perekonomian menuntut kemampuan untuk melakukan simulasi-simulasi tersebut sehingga pengendalian inflasi untuk tetap mencapai target yang telah ditentukan dapat dilakukan secara efektif.

*) Charles Joseph : Peneliti ekonomi di Bagian Studi Ekonomi Makro, Direktorat Riset Ekonomi dan Kebijakan Moneter, Bank Indonesia

Janu Dewandaru : Peneliti Ekonomi Yunior di Bagian Studi Ekonomi Makro, Direktorat Riset Ekonomi dan Kebijakan Moneter, Bank Indonesia

Hidayah Dhini Ari : Asisten Peneliti Ekonomi di Bagian Studi Ekonomi Makro, Direktorat Riset Ekonomi dan Kebijakan Moneter, Bank Indonesia

1 Pengembangan Model GEMBI dilakukan bekerjasama dengan USAID, dan Prof. Paul D. McNelis sebagai Supervisor Consultant. 
Laporan ini mencoba mengulas secara rinci tujuan dari pembentukan General Equilibrium Model of Bank Indonesia (GEMBI), perbedaan GEMBI dengan model ekonometrik yang ada serta kegunaan GEMBI sebagai model makro utama (core macro model) dalam menganalisa berbagai kebijakan yang sudah dan akan ditempuh serta alat penunjuk arah bagi proyeksi berbagai variable makro jangka menengah dan panjang. Selain tujuan dan kegunaan GEMBI, laporan ini akan mencakup penjelasan rinci tentang stuktur GEMBI, dan hasil simulasi dari prototipe awal GEMBI yang telah dikembangkan selama tahun 2000 ini.

Untuk tahap pertama GEMBI merupakan prototipe yang cukup paripurna dalam mengkaitkan lintas antar-sektor seperti rumah tangga, produksi, moneter dan eksternal. Dalam pengembangannya, model prototype ini masih akan diperluas lebih lanjut dengan melengkapinya dengan sub-sektor perbankan dan sub-sektor fiskal.

Laporan ini terdiri dari tujuh bab. Bab pertama merupakan tinjauan umum tentang GEMBI. Selanjutnya bab II meguraikan perbedaan General Equilibrium Model dan Macro Econometric model, serta kegunaan GEMBI sebagai alat evaluasi kebijakan dan penunjuk arah jangka menengah-panjang. Bab III menguraikan ciri struktural prototipe awal GEMBI yang telah dikembangkan GEMBI. Bab IV mengulas bagaimana mekanisme transmisi kebijakan moneter dalam GEMBI. Bab V mempresentasikan berbagai hasil simulasi alternatif kebijakan dalam rangka inflation targeting. Bab VI memberikan arah pengembangan model selanjutnya. BAB VII merupakan penutup.

\section{General Equilibrium Model}

Sejak akhir abad 19 ilmu ekonomi berkembang cukup pesat. Perkembangan tersebut ditandai oleh dua aliran utama (programme of scientific research) yakni Neo-Walrasian programme dan Keynesian programme. ${ }^{2}$ Perbedaan kedua madzab ini terlihat pada penekanannya dalam dasar-dasar teori ekonomi yang dipakainya. Neo-Walrasian lebih menekankan aspek micro foundations (konsep utilitas, keterbatasan dana, optimisasi pelaku ekonomi dan pencapaian keseimbangan umum), sementara Keynesian programme kurang menekankan konsep micro foundation terutama dalam pengembangan model-model makro.

Secara ringkas, sampai awal tahun 1970an pengembangan teori ekonomi sebagai scientific research programme masih ditandai oleh terpisahnya micro theory dan macro theory. Macro model yang dikembangkan saat itu lebih banyak diarahkan untuk menganalisa naik turunnya produksi, pendapatan dan pengeluaran secara agregat dan perkembangan harga (inflasi) sebagai akibat gagalnya koordinasi kebijakan makro (fiskal dan moneter). Model makro ini dibangun didasarkan pada abstraksi dunia nyata yang dituangkan dalam

2 Sawyer, John A, Macroeconomic Theory : Keynesian and New Walrasian Models, University of Pennesylvania Press, Philadelphia, 1989. 
persamaan-persamaan tunggal (contoh: persamaan konsumsi, investasi, pengeluaran pemerintah dll) untuk kemudian digabung secara simultan dalam satu model makro paripurna yang lebih dikenal sebagai Keynesian deterministic model. Model-model semacam ini didasarkan pada teori yang eksplisit, biasanya dengan memasukkan time lag serta dipakai untuk forecast jangka pendek. ${ }^{3}$ Model semacam ini mengalami kejayaannya di tahun 19501960an seiring dengan kemajuan teori Keynes.

Kejayaan model ini pudar di tahun 1970an dan dianggap usang sebagai Dinosaurs model karena model tersebut tidak mampu menjelaskan fenomena stagnasi (gabungan antara tingginya tingkat pengangguran dan inflasi) serta ketidakpastian hubungan antar berbagai variabel makro yang sangat dipengaruhi oleh stochastic shocks.

Revolusi rational expectation oleh Sargent dan Lucas di tahun 70an mengkritik model kovensional ini karena model-model tersebut mengandung sistematic error dan internally inconsistent. Model ini dianggap internally inconsistent karena mereka tidak mampu menampung setiap perubahan ekspektasi pelaku ekonomi dalam mengambil keputusan rasional. Model ini melalaikan asumsi bahwa setiap pelaku ekonomi adalah mahluk rasional yang tidak dapat terus menerus ditipu oleh kebijakan pemerintah yang datang secara tiba-tiba (unexpected/unannounced policies). Pelaku ekonomi akan selalu menyesuaikan perilakunya terhadap setiap perubahan kebijakan dan mengambil keputusan rasional (untuk melakukan konsumsi, investasi, mengalihkan tabungan saat ini atau dikemudian hari dll) berdasarkan informasi baru yang diperolehnya. Dalam menyesuaikan perilakunya, pelaku ekonomi yang rasional ini akan berupaya untuk selalu memaksimumkan utility preference nya dan memperhitungan keterbatasan sumber dana yang ada (budget constraint). Salah satu kegagalan macro-econometric model yang konvensional adalah mereka tidak memasukkan asumsi rational expectation yang pada hakekatnya merupakan faktor yang sangat penting dalam mempengaruhi perubahanperubahan dari setiap parameter yang diestimasi. Dalam model konvensional parameter dianggap konstan. Padahal setiap perubahan ekspektasi masyarakat yang disebabkan oleh perubahan kebijakan akan membuat parameter yang diestimasi ikut berubah. Oleh karena itu Lucas berpendaat, bahwa macro-econometric model kurang dapat diandalkan sebagai alat untuk mengevaluasi kebijakan ekonomi. Macro-econometric model mungkin baik untuk menforecast variabel makro untuk jangka pendek tapi tidak dapat dipakai sebagai alat untuk mengevaluasi kebijakan ekonomi yang biasanya berdampak dengan time-lag untuk jangka menengah dan jangka panjang.

Pada awal 1980an, diprakarsai oleh Kydland dan Prescott, teori siklus usaha (business cycle theory) mencoba menelaah siklus ekonomi yang lebih banyak disebabkan oleh gejolak

3 Diebold, Francis X, The Past, Present, and Future of Macroeconomic Forecasting,, Universitiy of Pennsylvania and NBER, October 22, 1997 in Journal of Economics Perspective (1998) 12 : 175-192. 
produktivitas produsen/kemajuan teknologi (productivity/technological shocks). Teori ini mencoba menerapkan berbagai pendekatan micro dalam macro modelling di negara-negara maju. Menurut business cycle theory, perubahan endogenous variables tidak saja ditentukan oleh adanya perubahan kebijakan makro tetapi sangat dipengaruhi oleh adanya ketidakpastian yang tercermin dalam productivity/technological shocks. Selanjutnya, Enrique Mendoza $^{4}$ mencoba menerapkan teori business cycle ini untuk menganalisa keadaan di negara-negara berkembang. Menurut Mendoza, siklus usaha di negara berkembang bukan dipengaruhi oleh technological shocks melainkan lebih banyak dipengaruhi oleh terms of trade shocks. Secara ringkas dapat disimpulkan bahwa sejak tahun 1980an macro modelling banyak menerapkan business cycles approach. Sejak saat itu terjadi merging antara macro dan micro economic foundation. Fenomena dalam macro economics ini sering disebut sebagai New Classical-Keynesian synthesis.

\section{A. Tujuan Macro Modeling}

Pada dasarnya ada dua tujuan utama dari macro modeling. Yang pertama untuk "economic projection" dan yang kedua adalah untuk "policy simulation".

Macro modeling yang diarahkan untuk economic projection biasanya bercirikan jangka pendek dan memakai banyak data historis (time series) dari dunia nyata yang diolah dengan metode ekonometrik. Sedangkan policy simulation biasanya lebih bersifat jangka menengah dan panjang (2 sampai 5 tahun ke depan), sangat berorientasi teoritis dan kemampuannya untuk menjelaskan fenomena dunia nyata dapat divalidasikan dengan data historis. Model yang dipakai untuk policy simulation ini bersifat dinamis (dynamic path) dan disusun berdasarkan prinsip general equilibrium serta dioperasikan dengan memasukkan shocks yang bersifat stochastic. Oleh karenanya model semacam ini lebih sering dikenal sebagai Dynamic Stochastic General Equilibrium (DSGE). Dengan lain kata, hasil simulasi DSGE dikatakan baik dan konsisten apabila hasil simulasi tersebut (dari data artificial shocks) harus mirip atau memiliki property yang sama dengan apa yang dicerminkan oleh data historis yang diolah oleh model ekonometrik (historical data generating model). Sebagai contoh bila koefisien korelasi dari dua variable berdasarkan simulasi DSGE mendekati koefisien korelasi yang diperoleh dari model ekonometrik (data historis) maka model DSGE dapat dianggap robust dalam mengabstraksi dunia nyata.

Biasanya terdapat trade off antara projection accuracy yang dihasilkan dari model ekonometrik dan medium-long term policy evaluation yang diperoleh dari DSGE model. Proyeksi yang dihasilkan dari econometric model belum tentu sepadan dan searah dengan hasil dikeluarkan oleh simulasi DSGE model.

4 Mendoza, Enrique G (1995), “The Terms of Trade, the Real Exchange Rate, and Economic Fluctuations”, International Economic Review 36: 101-137. 


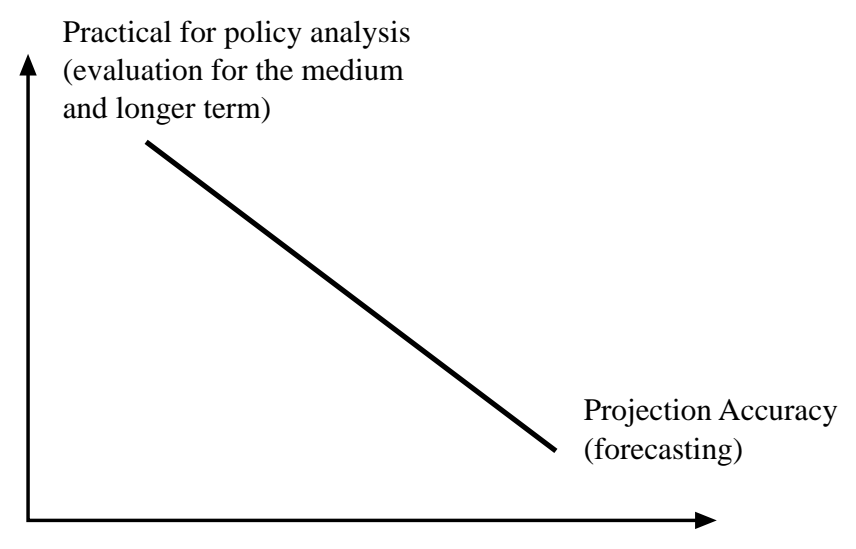

Proyeksi jangka pendek berdasarkan goodness of fit yang baik dari model ekonometrik, belum tentu selaras dengan hasil simulasi DSGE model. Hal ini dapat dianalogikan dengan kasus di bidang medis.

Hubungan negatif antara Aspirin dan Demam yang dihasilkan dari regresi sederhana mungkin baik untuk dipakai sebagai pedoman dalam mengobati pasien yang menderita demam. Namun, kesimpulan hasil regresi tersebut tidak dapat dipakai sebagai pedoman mutlak dalam mengobati demam dalam jangka panjang. Mengapa? Karena regresi sederhana tersebut tidak memasukkan unsur yang mendasari adanya demam yaitu "infeksi" sebagai penyebab utama demam tersebut.

Memakai regresi sederhana untuk mengobati demam jangka pendek mungkin dapat diandalkan sebagai penunjuk gejala demam jangka pendek, tapi regresi tersebut belum tentu cocok diterapkan bila demam tersebut masih berlangsung untuk jangka yang lebih lama (menengah-panjang).

Sama halnya dengan kasus diatas, econometric models dapat diandalkan untuk memforecast variable ekonomi jangka pendek (satu triwulan atau satu tahun ke depan), namun estimasi keterkaitan antar variable (estimated relationship) yang dihasilkan oleh econometric model tidak dapat dipakai sebagai patokan untuk mengevaluasi suatu kebijakan (policy evaluation). Seperti lazimnya model ekonometrik, model makro yang dibangun dengan metode ekonometrik selalu berasumsi bahwa keterkaitan antar variable (parameter yang diestimasi berdasarkan data historis) bersifat tetap (konstan) untuk jangka panjang. Sebagai contoh, secara ekonometrik terdapat hubungan konstan antara konsumsi, pendapatan dan kekayaan. Hubungan konstan tersebut diperoleh dari data historis masa lampau (past experience) yang sebenarnya melupakan adanya unsur ekspektasi pelaku ekonomi yang selalu berubah-ubah berdasarkan informasi baru yang diterima. Dengan berubahnya ekpektasi pelaku ekonomi, keterkaitan antar variable diatas akan ikut berubah atau tidak lagi konstan. 
Pendekatan ekonometrik seperti ini merupakan bahan kritikan dari Robert Lucas yang sering dikenal sebagai "Lucas Critique".

Keterkaitan antar variable yang diestimasi (estimated relationship) pada hakekatnya mencerminkan serangkaian keterkaitan struktural yang lebih mendalam (deeper structural relationship) yang diperoleh dari fundamentals of preference and technology dan dari pembentukan ekspektasi pelaku ekonomi. Seandainya salah satu dari komponen struktural seperti ekspektasi, preferensi atau teknologi berubah akibat perubahan regim kebijakan maka sangatlah sulit mengestimasi parameter dengan memakai metode ekonometrik. Kesulitan tersebut disebabkan karena econometric model tidak memasukkan underlying factors seperti ekspektasi, preferensi dan teknologi yang mendasari keterkaitan antar variable. Econometric model hanya mampu memforecast besaran variabel makro berdasarkan data historis dan mengasumsikan bahwa hubungan antar variable makro adalah konstan untuk jangka panjang. Salah satu kritik yang diajukan oleh Lucas (Lucas critique) adalah estimated relationship of macroeconometric models will no longer hold good if the policy regime changes, because expectations are likely to depend on the regime.

Oleh karena itu, econometric models tidak dapat diandalkan untuk mengukur dan mengevaluasi perubahan regim kebijakan (policy rules) yang biasanya berdampak jangka menengah-panjang. Setiap perubahan regim kebijakan selalu ditanggapi serius oleh pelaku ekonomi yang secara serentak akan merubah pola keputusan mereka dalam berkonsumsi, menabung dan berinvestasi. Akibatnya, pola dari konsumsi, investasi, permintaan uang dan variable makro lainnya akan berubah serentak. Pola tersebut sering kali berbeda dengan pola yang telah diforecast oleh model ekonometrik. Untuk mengatasi hal ini diperlukan General Equilibrium model yang lebih ampuh dalam menganalisa pola perubahan variable makro (dynamic paths) akibat perubahan regim kebijakan yang berdampak jangka menengah-panjang dan konsisten secara teori (theoretically consistent).

Pendekatan yang dilakukan dalam mengembangkan GEMBI disebut sebagai Integrated Approach, dimana General Equilibrium dan Macroeconometric Approach dipadukan dalam satu kesatuan yang terpadu. Sebagai contoh, selisih antara data historis (actual data) dan hasil forecast yang diperoleh secara econometrics (residual error) dapat dijadikan sebagai input oleh GEMBI untuk menghasilkan dynamic path. Contoh lainnya, GEMBI juga dapat memodelkan shocks yang diperoleh dari Vector Autoregression. Integrated approach ini juga mencakup pengembangan model dasar (simple core model) GEMBI ke bentuk model yang lebih rinci menurut sub-sektor seperti sub-sektor perbankan dan sub-sektor fiskal.

\section{B. Ciri-ciri khas Dynamic Stochastic General Equilibrium Model (GEMBI)}

- Berbeda dengan model-model ekonometrik, GEMBI dibangun berdasarkan keterkaitan persamaan-persamaan simultan dan dijalankan tidak dengan memakai data historis (time 
series) melainkan dengan data artificial shocks yang bersifat random. Shocks yang random ini akan direspon oleh seluruh pelaku ekonomi dengan spesifikasi yang terinci.

- Spesifikasi tersebut didasarkan pada teori mikro (micro-foundations) dimana masingmasing pelaku ekonomi (konsumen, produsen, pemerintah dan bank sentral) akan memaksimumkan utilitasnya dan bergerak dalam batasan anggaran mereka (budget constraints).

- Dengan konsep optimisasi tersebut diperoleh first order condition (dengan memakai metode persamaan Bellman atau Langrange) yang dipakai sebagai dasar untuk menghitung pola pergerakan (dynamic path) laju konsumsi, laju inflasi, gerakan nilai tukar riil dan nominal dan variable makro lainnya dalam jangka panjang.

- Hasil simulasi DSGE ini immune terhadap Lucas Critique, karena model ini telah memasukkan unsur ekspektasi ke depan (forward looking expectation) dimana pelaku ekonomi akan berorientasi ke depan dan menyesuaikan segala tindakannya terhadap shocks yang terjadi.

- Model ini dapat dipakai sebagai alat penunjuk arah (kompas)/ disciplinary device dalam mengevaluasi berbagai alternatif kebijakan (changes in policy rules) dibanding dengan model ekonometrik yang diandalkan untuk proyeksi jangka pendek yang lebih bersifat reaktif terhadap perubahan kebijakan jangka pendek.

- GEMBI tidak memberikan angka proyeksi/forecasting figures melainkan hanya menunjukkan dynamic path dari berbagai variable-variabel makro (konsumsi, investasi, kapital stok, harga) dalam jangka menengah-panjang berdasarkan simulasi dari berbagai alternatif kebijakan perubahan kebijakan (policy rules).

- GEMBI dikembangkan dengan Top-down Approach, artinya ia dikembangkan secara integrated dimana terlihat keterkaitan antara sektor rumah tangga, sektor moneter, sektor fiskal dan sektor eksternal dalam satu kesatuan sistem untuk kemudian diperluas menurut sub-sektor (rincian dari sektor fiskal, moneter dan perbankan).

- GEMBI lebih cocok untuk inflation targeting environment dimana berbagai Taylor Rules Startegy dapat dimasukkkan kedalam model untuk disimulasi. Hasil dari berbagai $d y$ namic path yang diperoleh dari berbagai policy rules akan dievaluasi untuk menentukan policy rule yang terbaik untuk diterapkan oleh pembuat kebijakan.

- GEMBI dapat dipakai sebagai flight simulator economy subject to turbulence dimana seseorang dapat memakai model ini untuk mengukur berbagai alternatif kebijakan dalam lingkungan yang terus menerus diserang oleh berbagai shocks. Bukankah dalam dunia nyata setiap saat para pelaku ekonomi selalu diperhadapkan pada ketidak pastian (shocks)? 


\section{GEMBI dan keterkaitannya dengan MODBI dan MODBIQ}

Keterkaitan antara GEMBI dengan model-model makroekonometrik lainnya (MODBI dan MODBIQ) dapat digambarkan dalam diagam sebagai berikut:

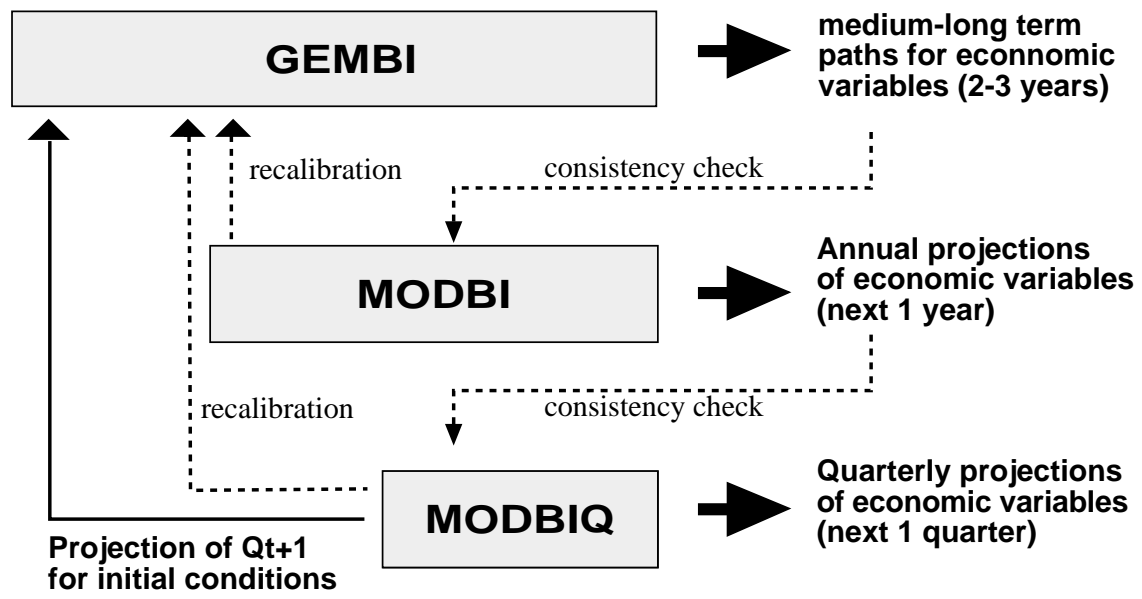

Mengingat GEMBI merupakan integrated model yang akan dipakai sebagai flight simulator untuk mensimulasi berbagai policy rules untuk menunjukkan dynamic path jangka menengah dan panjang (2-5 tahun kedepan), GEMBI memerlukan masukkan berupa hasil forecast (satu kuartal ke depan atau satu tahun ke depan) dari MODBIQ dan MODBI. Forecast ini akan dipakai sebagai nilai awal (initial value) bagi GEMBI untuk menentukan $d y$ namic path beberapa kuartal/tahun ke depan. Dari path yang dihasilkan GEMBI, tim MODBIQ dan MODBI dapat menyesuaikan simulasi yang mereka jalankan dengan metode ekonometrik untuk menghasilkan short-term projection/forecast yang konsisten dengan longterm dynamic path.

\section{Proses dalam Pengembangan GEMBI}

Pengembangan model dynamic general equilibrium untuk evaluasi kebijakan pada umumnya dilakukan sebagai berikut :

- Theoretical specification : yakni menetapkan secara rinci fungsi obyektif (objective function), keterbatasan dana (budget constraints), dan teknologi.

- Derivation : yakni menggunakan dunamic programming untuk memecahkan persamaan Euler (pemecahan masalah optimisasi).

- Stochastic specification : yakni memproses estimasi dari semua shocks eksogen yang muncul.

- Calibration : yakni menetapkan nilai bagi semua parameter dan kondisi awal. 
- Solution : yakni mencari solusi dari forward looking variables dengan algorithm.

- Validation : yakni mensimulasikan model dan membandingkan data artifisial dengan data historis.

- Simulation of policies : yakni membandingkan alur dinamik untuk jangka menengah dan panjang.

- Sensitivity analysis : yakni mengevaluasi kuat tidaknya berbagai hasil simulasi terhadap variabel tertentu.

Proses pengembangan model general equilibrium seperti tersebut diatas oleh McCallum ${ }^{5}$ dapat digambarkan sebagai berikut:

1 Dalam pemakaian model general equilibrium yang dinamis, para pelaku ekonomi digambarkan sebagai mahluk yang memecahkan masalah dynamic optimization dan berinter-aksi dalam pasar persaingan sempurna, namun dengan memasukkan bentuk nominal price/wage stickiness;

2. Kemiripan dari model ini dengan data aktual kemudian diamati dengan melihat interaksi antar berbagai variabel riel maupun variabel moneternya.

3. Tujuan dari upaya semacam ini adalah memungkinkan pengamat ekonomi untuk mengkombinasikan disiplin teori general equilibrium dalam mengamati data empiris dimana harga tidak secara otomatis menyesuaikan secara cepat (instant).

Upaya menerapkan general equilibrium ini benar-benar sangat mendasar dan kebal terhadap Lucas critique dan sangat cocok untuk analisa kebijakan.

\section{STRUKTUR GEMBI}

Model General Equilibrium yang digunakan sebagai dasar untuk menyusun prototipe GEMBI diambil dari model short-run macroeconomics dynamics oleh Pierre-Richard Agenor dan Peter J.Montiel ${ }^{6}$. Namun demikian, dalam perkembangan selanjutnya telah dilakukan pengembangan dan modifikasi terhadap model dasar tersebut. Model yang akan dipaparkan di bawah ini merupakan hasil pengembangan dari model dasar, antara lain berupa pengembangan dari one-good model menjadi two-goods model (traded dan non-traded goods), dimasukkannya unsur capital dalam komponen asset, digunakannya variabel ekspektasi dalam penentuan konsumsi dan nilai tukar, serta dimasukkannya unsur price rigidities ke dalam persamaan harga.

5 McCallum, B., "Recent Developments in the Analysis of Monetary Policy Rules", Federal Reserves Bank of St.Louis Review, November/December 1999.

6 Agenor P.R. and P.J.Montiel, "Development Macroeconomics”, Princeton University Press, New Jersey, 1996. 


\section{A. Asumsi-Asumsi}

- Model mengasumsikan suatu open economy, dengan pelaku ekonomi terdiri dari produsen, rumahtangga, pemerintah, dan bank sentral.

- Pada sisi produksi, domestic output terdiri dari tradable dan nontradable goods yang dihasilkan dengan menggunakan capital sebagai faktor produksi.

- Purchasing Power Parity (PPP) berlaku selamanya. Pada sistem nilai tukar tetap, mata uang domestik terdepresiasi dengan laju yang tetap, sehingga perubahan cadangan devisa merupakan mekanisme penyesuai untuk menjaga nilai tukar tetap. Pada sistem nilai tukar mengambang, tidak ada perubahan stok cadangan devisa karena bank sentral tidak melakukan intervensi sama sekali.

- Model dibangun berdasarkan asumsi perfect capital mobility.

- Rumah tangga domestik memegang dua jenis aset: mata uang domestik dan obligasi pemerintah. Rumah tangga domestik dapat melakukan pinjaman luar negeri dari world capital markets, yang besarnya dipengaruhi oleh besarnya premium dari pinjaman. Diasumsikan dalam model, bahwa besarnya premium yang harus dibayar berkorelasi positif dengan jumlah pinjaman. Semakin besar pinjaman, semakin tinggi premium yang harus dibayar.

- Pemerintah melakukan konsumsi barang dan jasa, menarik lump-sum taxes, membayar kewajiban bunga dari obligasi yang ia keluarkan, dan membiayai defisit anggarannya dengan cara menerbitkan obligasi di dalam negeri.

\section{B. Prototipe Model}

Prototipe GEMBI dibangun dari persamaan-persamaan yang dapat digolongkan ke dalam 3 jenis persamaan yaitu :

I. Static Equations

II. Backward-Looking Dynamic Equations

III. Forward-Looking Dynamic Equations

\section{B.1. Static dan Backward-Looking Dynamic Equations}

\section{a. Konsumsi}

Agen representatif melakukan optimisasi dua tahap. Pada tahap pertama, agen memaksimumkan utilitas untuk memperoleh tingkat konsumsi yang optimal dan pada tahap kedua, agen mengalokasikan konsumsinya antara barang-barang yang tradeable dan non-tradable. 


\section{a.1 Maksimisasi Konsumen: Tahap Satu}

Bentuk fungsi utilitas pada tahap pertama adalah suatu constant (intertemporal) elasticity of substitution).

$$
\operatorname{Max} V=\int_{e^{-p t}}\left[\frac{c^{1-\eta}}{1-\eta}+\chi \ln (m)\right]
$$

dimana $\rho$ adalah social discount rate, $c$ adalah consumption, dan $\eta$ adalah coefficient of relative risk aversion. Uang, $m$, secara eksplisit dimasukkan dalam fungsi utilitas dengan argumen meningkatkan kenyamanan dalam transaksi (medium of exchange).

Total aset (A) yang dimiliki oleh seorang agen terdiri dari uang, kapital dan government bonds dikurangi dengan jumlah hutang luar negeri, sehingga menjadi :

$$
A=M+K+B-L^{*}
$$

dimana $\boldsymbol{M}$ merupakan stok uang nominal, $\boldsymbol{K}$ kapital, $\boldsymbol{B}$ stok bonds, dan $E L^{*}$ stok pinjaman luar negeri dalam domestic-currency. $E$ adalah nilai tukar nominal dan $L^{*}$ pinjaman luar negeri dalam foreign-currency. Dalam bentuk riil, persamaan (2) dapat ditulis sebagai:

$$
a=m+k+b-l^{*}
$$

dimana $a=A / P, \quad m=M / P, k=K / P, \quad b=B / P, l^{*}=E L^{*} / P$, sehingga budget constraint dari fungsi optimisasi (1) adalah sebagai berikut:

$$
\begin{aligned}
& c_{t}+k_{t+1}+b_{t+1}+m_{t+1}-l^{*}{ }_{t+1}=f\left(k_{t}\right)+k_{t}(1-\delta)-\frac{\phi^{k}}{2}\left(k_{t+1}-k_{t}\right)^{2}+m_{t}(1-\pi)+ \\
& b_{t}(1+i-\pi)-l^{*}\left(1+i^{*}+\theta\right)
\end{aligned}
$$

dimana :

$$
\begin{aligned}
c_{t} & =\text { consumption } \\
k_{t+1} & =\text { capital stock } \\
b_{t} & =\text { government bonds } \\
m_{t} & =\text { money stock } \\
l^{*} & =\text { foreign debt } \\
f\left(k_{t}\right) & =\text { output at time } t \\
\delta & =\text { depreciation rate of capital stock } \\
\frac{\phi^{k}}{2} & =\text { adjustment cost parameter in capital accumulation } \\
m_{t} \pi & =\text { inflation tax } \\
\theta & =\text { risk premium }
\end{aligned}
$$


Persoalan optimisasi persamaan (1) dengan kendala (4) selanjutnya diselesaikan dengan metode Bellman atau Lagrange Dan dari first order conditions-nya diperoleh solusi untuk konsumsi sebagai berikut:

$$
\frac{c^{\bullet}(t)}{c(t)}=\sigma(r-\rho)
$$

dimana $\sigma=1 / \eta$, adalah elastisitas substitusi intertemporal.

Euler equation ini meperlihatkan, bahwa naik-turunnya konsumsi ditentukan oleh apakah domestic real interest rate lebih besar atau lebih kecil daripada the rate of time preference.

\section{a.2 Maksimisasi Konsumen: Tahap Kedua}

Dalam tahap kedua, agen representatif mengalokasikan tingkat konsumsi optimal pada barang non-traded (cN) dan traded (cT) dengan memaksimumkan fungsi homothetic sub-utilitas $\mathrm{V}\left(c_{\mathrm{N}}, c_{\mathrm{T}}\right)$ terhadap intra-temporal budget constraint.

$$
\operatorname{Max} V\left(c_{N^{\prime}} c_{T}\right)
$$

terhadap suatu static budget constraint:

$$
\text { P.c }=P_{N} c_{N}+E c_{T}
$$

di mana PN adalah price of home goods, $\mathrm{CN}$ adalah konsumsi non-tradable goods, dan CT adalah konsumsi tradable goods. Fungsi sub-utilitas V diasumsikan Cobb-Douglas:

$$
V\left(c_{T}, c_{N}\right)=c_{N}^{\delta} c_{T}^{1-\delta}
$$

di mana $0<\delta<1$ adalah porsi konsumsi non-tradable dalam total pengeluaran. Dengan menggunakan metode Lagrange dan dari first order conditions, diperoleh solusi konsumsi traded dan non-traded sebagai fungsi dari $\mathbf{z}$ dan total expenditure $\mathbf{c}$ sebagai berikut :

$$
\begin{aligned}
& c_{T}=(1-\delta) z^{-\delta} c \\
& c_{N}=\delta z^{1-\delta} c
\end{aligned}
$$

dimana $\mathbf{z}$ adalah real exchange rate yang didefinisikan sebagai $z=E / P_{N}$ 
b. Money demand function

$$
m=\frac{\chi}{i} c^{\eta}
$$

Fungsi permintaan uang diperoleh dengan menyamakan marginal rate of substitution antara money balances dan konsumsi dengan opportunity cost dari memegang uang cash, yaitu besarnya tingkat suku bunga.

\section{c. Harga dan Inflasi}

Dengan definisi consumer price index $P=P_{N}^{\delta} E^{1-\delta}$ dan real exchange rate $z=E / P_{N}$, maka consumer price index tersebut dapat ditulis sebagai fungsi dari z:

$$
P=E z^{-\delta}
$$

dan inflasi dapat ditulis sebagai berikut:

$$
\begin{aligned}
\pi & =\ln P_{t}-\ln P_{t-1} \\
& =\left(\ln E_{t}-\delta \ln z_{t}\right)-\left(\ln E_{t-1}-\delta \ln z_{t-1}\right) \\
& =\left(\ln E_{t}-\ln E_{t-1}\right)-\delta\left(\ln z_{t}-\ln z_{t-1}\right) \\
\pi & =\varepsilon-\delta \frac{\&}{z}
\end{aligned}
$$

\section{d. Kapital dan Output dari Traded Goods}

Dalam GEMBI digunakan fungsi produksi Cobb-Douglas sebagai berikut :

$$
f\left(k_{t}\right)=\left[\varepsilon_{t}^{T} A k_{t}^{\alpha}\right]
$$

dimana $\varepsilon_{t}=$ terms of trade shock

$\mathrm{A}=$ coefficient of production function

$\alpha=$ share of capital in production function

$f\left(k_{t}\right)=y_{t}=$ output dari sektor traded goods 
Berdasarkan budget constraint pada (4) dan first order condition-nya, diperoleh solusi untuk pembentukan kapital sebagai berikut :

$$
\frac{R_{t}\left[1+\phi \quad\left(k_{t}-k_{t-1}\right)\right]-(1-\delta)-\phi\left(k_{t+1}-k_{t}\right)}{\varepsilon_{t}^{T} \alpha A}=k_{t}^{*}
$$

Dalam fungsi produksi pada (13), ouput dari traded sector merupakan fungsi dari capital stock at time $t\left(k_{t}\right)$. Hal ini kurang realistis mengingat terdapatnya time lag, antara planned capital dan productive capital. Mengikuti Black, Casino, Drew, Hansen, Hunt, Rose, dan Scott (1997) pada spesifikasi New Zealand FPS Model, dinyatakan bahwa output aktual dari traded sector bukan merupakan fungsi dari capital stock at time $t\left(k_{t}\right)$, melainkan dari productive capital at time $t\left(k p_{t}\right)$, yang merupakan fungsi dari current dan past stocks of capital. Dalam GEMBI, productive capital at time $t\left(k p_{t}\right)$ ditentukan dengan spesifikasi sebagai berikut :

$k p_{t}=\alpha_{1}\left(k_{t-1}\right)+\alpha_{2}\left(k_{t-2}\right)+\alpha_{3}\left(k_{t-3}\right)+\alpha_{4}\left(k_{t-4}\right)+\alpha_{5}\left(k_{t-5}\right)+\alpha_{6}\left(k_{t-6}\right)+\alpha_{7}\left(k_{t-7}\right)-\alpha\left(k p_{t-1}\right)$

dimana $\sum_{k=0}^{7} \alpha_{k} \quad \begin{aligned} & \text { bobot dari capital stock periode } t-k \text { terhadap pembentukan capital produc- } \\ & \text { tive periode } t\end{aligned}$

Dengan demikian, fungsi produksi untuk traded sector menjadi :

$$
f\left(k_{t}\right)=y_{t}=\left[\varepsilon_{t}^{T} A k p_{t}^{\alpha}\right]
$$

\section{e. Bank sentral}

Suplai uang dalam bentuk riil dapat diekspresikan sebagai fungsi dari real exchange rate $\mathrm{z} \mathrm{sbb}$ :

$$
\begin{aligned}
& \frac{M^{S}}{P}=\frac{E R^{*}}{P}+\frac{D}{P} \\
& m^{S}=z^{\delta} R^{*}+d
\end{aligned}
$$

di mana $m$ adalah real money balances, $R^{*}$ stock of net foreign assets dalam mata uang asing dan $d$ adalah real stock of domestic credit yang diberikan oleh bank sentral kepada pemerintah. Mengingat dalam model prototipe ini diasumsikan tidak ada lembaga finansial lain, maka sumber perubahan money supply adalah dari perubahan net foreign asset dan/ atau kredit yang diberikan oleh bank sentral kepada pemerintah. Besarnya pertumbuhan 
domestic credit (=kredit yang diberikan kepada pemerintah) ditentukan oleh bank sentral dengan formula:

$$
d_{t}-d_{t-1}=(\mu-\pi) d_{t-1}
$$

di mana $\mu$ adalah laju pertumbuhan kredit nomimal dan $\pi$ adalah inflasi.

\section{f. Pemerintah}

Pada sektor pemerintah, perubahan government bonds merupakan respon dari kondisi keuangan pemerintah. Kenaikan defisit anggaran pemerintah akan direspon dengan meningkatnya penerbitan government bonds. Sehingga budget constraint pemerintah ditulis sebagai berikut:

$$
b^{\bullet}=z^{\delta}\left(g_{T}+g_{N} / z\right)-\pi m-\tau+r b-z^{\delta}\left(i^{*}+\varepsilon\right) R^{*}
$$

dimana :

$b$

$g_{T}$ dan $g_{N} \quad$ belanja pemerintah untuk traded goods dan non-traded goods;

$r b$

$\pi m$

$z^{\delta}\left(i^{*}+\varepsilon\right) R^{*}$

stok hutang pemerintah dalam bentuk domestic bonds inflation tax/ seigniorage; beban pembayaran bunga atas government bond yang dikeluarkan; sebagian dari real capital gains atas cadangan devisa yang diberikan oleh bank sentral kepada pemerintah.

\section{g.Sektor Eksternal}

\section{g.1. Hutang luar negeri}

Akumulasi hutang luar negeri dalam bentuk riil merupakan respon terhadap kondisi current account deficit dan net international payments (capital account):

$$
l_{t}^{*}-l_{t-1}^{*}=i^{*} l_{t-1}^{*}+\theta\left(l_{t-1}^{*}\right) l_{t-1}^{*}+(1-\delta) z^{-\delta} c+g_{T}-y_{T}^{S}
$$

Untuk current account, $(1-\delta) z^{-\delta} c+g_{T}-y_{T}^{S}$,diasumsikan bahwa terdapat suatu quantity adjustment pada sektor produksi tradable goods, sehingga excess demand akan 
menyebabkan trade deficits dan excess supply akan menyebabkan trade surplus. Sementara itu, net international payments $i^{*} l_{t-1}^{*}+\boldsymbol{\theta}\left(l_{t-1}^{*}\right) l_{t-1}^{*} \mid$ ditentukan oleh besarnya pembayaran bunga hutang luar negeri dan risk premium.

\section{g.2. Nilai tukar}

Harga barang-barang di sektor non-traded diasumsikan 'sticky', yaitu harga barangbarang non traded hanya melakukan penyesuaian parsial terhadap ekses suplai dan permintaan. Sehingga inflasi pada sektor barang-barang non traded dapat ditulis sebagai:

$$
\underline{\ln \left(P_{N, t}-P_{N, t-1}\right)=\gamma\left[\delta z^{1-\delta} c+g_{N}-y_{N}^{S}\right]}
$$

Dan perubahan nilai real exchange rate $\mathrm{z}$ merupakan fungsi dari tingkat inflasi pada sektor barang non-traded sebagai berikut:

$$
\ln \left(z_{t}\right)-\ln \left(z_{t-1}\right)=\left[\ln \left(E_{t}\right)-\ln \left(E_{t-1}\right)\right]-\left\lfloor\ln \left(P_{n, t}\right)-\ln \left(P_{n, t-1}\right)\right\rfloor
$$

Meningkatnya harga barang-barang non-traded, misalnya sebagai akibat dari kenaikan upah pekerja pada sektor tersebut, akan menyebabkan real exchange rate ter-apresiasi.

\section{B.2. Forward-Looking Dynamic Equations}

Salah satu permasalahan dalam GEMBI adalah adanya beberapa forward looking variabel dalam model, yaitu nilai tukar nominal $\left(E_{t}\right)$ dan konsumsi $\left(c_{t}\right)$. Adapun persamaan dari variabel tersebut adalah sebagai berikut :

$$
\begin{aligned}
& \left.\ln \left(E_{t+1}\right)-\ln \left(E_{t}\right)=i-i^{*}+\theta-l^{*} \theta_{l^{*}}\right] \\
& \ln \left(c_{t+1}\right)-\ln \left(c_{t}\right)=\sigma(-\rho)
\end{aligned}
$$

yang menyatakan bahwa nilai tukar nominal pada time $t$ akan ditentukan oleh ekspektasi nilai tukar nominal pada time $t+1$ dan interest rate differential, yaitu $\left.i-i^{*}+\theta-l^{*} \theta l^{*}\right]$. Demikian pula konsumsi pada time $t$ akan ditentukan oleh ekspektasi konsumsi pada time $t+1$ dan selisih antara real interest rate $r$ dan social discount rate $\rho$.

Menurut Sims (2000), nilai dari suatu variabel yang dapat diamati pada saat sekarang (time $t$ ) adalah nilai sekarang (current values) dan nilai masa lalu (past values). Dengan 
demikian, nilai dari $\ln \left(E_{t+1}\right)$ dan $\ln \left(c_{t+1}\right)$ harus diproksi dengan nilai ekspektasi dari variabelvariabel tersebut, sehingga diperoleh :

$$
\begin{aligned}
& \ln \left(E_{t+1}\right)=\ln \left({ }_{t} E_{t+1}\right)+\xi_{E, t} \\
& \ln \left(c_{t+1}\right)=\ln \left({ }_{t} c_{t+1}\right)+\xi_{c, t}
\end{aligned}
$$

dimana operator $E_{t} E_{t+1}$ dan ${ }_{t} c_{t+1}$ merupakan ekspektasi terhadap nilai tukar dan konsumsi pada waktu $t$ untuk waktu $t+1$. Dengan demikian perlu dilakukan estimasi terhadap variabel-variabel ekspektasi.

Mengikuti Marcet (1988, 1993), Den Haan dan Marcet (1990,1994), serta Duffy dan McNelis (2000), estimasi terhadap variabel ekspektasi dapat dilakukan dengan menggunakan metode yang disebut Parameterized Expectations. Ide dasar dari metode ini adalah dilakukannya "parameterisasi" pada variabel ekspektasi, dengan menggunakan fungsi non-linier, $\psi^{E}, \psi^{C}$ :

$$
\begin{aligned}
& \ln \left({ }_{t} E_{t+1}\right)=\psi^{E}\left(x_{t-1} ; \lambda_{E}\right) \\
& \ln \left({ }_{t} c_{t+1}\right)=\psi^{c}\left(x_{t-1} ; \lambda_{c}\right)
\end{aligned}
$$

dimana $x_{t}$ merupakan vektor dari variabel-variabel teramati (observable variables) pada saat $t$, yaitu konsumsi, nilai tukar riil, produksi barang traded dan non-traded, sukubunga domestik dan internasional, serta risk premium,

$$
x_{t}=\left\{c, z, y_{T}, y_{n}, i, i^{*}, \theta\right\}
$$

dan $\lambda_{E}, \lambda_{c}$ merupakan vektor dari solusi yang meminimalkan error dari fungsi.

Solusi dari fungsi $\psi^{E}, \psi^{C}$ biasanya diestimasi dengan menggunakan pendekatan second-order polynomial expansions. Akan tetapi kelemahan dari pendekatan ini adalah kemungkinan adanya lebih dari satu optimum points, yang biasa ditemui pada fungsi-fungsi non-linier. Dengan demikian, solusi yang dihasilkan kemungkinan adalah local solution atau saddle point, sementara yang ingin ditemukan adalah global solution.

Untuk mengatasi masalah ini, digunakan pendekatan artificial neural network (ANN) dengan genetic algorithm sebagai metoda belajar (learning method). Sargent (1997) telah menunjukkan bahwa neural network lebih baik dalam melakukan estimasi terhadap fungsi non-linier dibandingkan dengan metode polynomial, dalam arti pendekatan neural network menghasilkan estimasi in-sample yang lebih baik dari pendekatan second-order polynomial expansions dengan menggunakan sejumlah parameter yang sama, atau menghasilkan estimasi dengan akurasi yang sama dengan menggunakan parameter yang lebih sedikit. 
Spesifikasi dari fungsi $\psi^{E}, \psi^{C}$ dengan menggunakan pendekatan neural network dilakukan dengan menggunakan persamaan-persamaan sebagai berikut :

$$
\begin{aligned}
& n_{k, t}=\sum_{j=1}^{J^{*}} b_{j} x_{j}, t \\
& N_{k, t}=\frac{1}{1+e^{-n_{i}, t}} \\
& \psi_{t}=\sum_{k=1}^{K^{*}} \kappa_{k} N_{k, t}
\end{aligned}
$$

dimana $J^{*}$ adalah jumlah variabel input/ eksogen, $K^{*}$ adalah jumlah dari simpul syaraf (neurons), $n_{t}$ adalah kombinasi linier dari variabel-variabel input, $N_{t}$ adalah logsigmoid atau $\log$ transformation dari $n_{t}$, dan $\psi_{t}$ adalah prediksi neural network untuk variabel $E_{t}$ dan $c_{t}$.

Langkah pertama yang dilakukan adalah membentuk neuron yang merupakan kombinasi linier dari variabel-variabel input. Selanjutnya neuron tersebut ditransformasikan ke dalam bentuk fungsi logsigmod. Dan dari sini proses dilanjutkan dengan menggunakan neuron yang telah ditransformasi tersebut untuk melakukan estimasi linier terhadap variabel dependen $\psi_{t}$.

Solusi fungsi $\psi^{E}, \psi^{C}$ yang diperoleh dari pendekatan neural network ini pada dasarnya dicapai dengan metode estimasi berulang (recursive estimation). Untuk memulai proses, parameter yang akan diestimasi $\left(\lambda_{E}, \lambda_{c}\right)$ di berikan suatu nilai awal (initial values) yang dipilih secara random. Setelah ini proses estimasi dapat dimulai.

\section{Validasi Model}

Validasi suatu model biasanya dilakukan dengan cara mengukur kemampuan dari model tersebut untuk menghasilkan data yang mendekati data asli-nya. Untuk general equilibrium (GE) model, validasi dapat dilakukan dengan cara membandingkan karakteristik-karakteristik dari data artificial yang diperoleh melalui simulasi GE model dengan data asli. Karakteristik tersebut dapat berupa rata-rata, standard deviasi, besarnya korelasi antar data, dan sebagainya. Alternatif lain adalah dengan menggunakan suatu metode yang disebut Validation through Auxiliary Models.

Pada dasarnya validation through auxiliary models dilakukan dengan memanfaatkan model ekonometrik yang ada untuk melakukan estimasi dengan menggunakan data artificial hasil simulasi GE model, dan kemudian hasil estimasi-nya dibandingkan dengan hasil estimasi model ekonometrik dengan menggunakan data asli. 
Ide dasar dari pendekatan ini sebenarnya sangat sederhana. Seperti yang dikemukakan oleh Craine, Lochester, dan Syrtveit (1999), pada dasarnya alam (nature) menciptakan 'sampel-sampel', yang berasal dari suatu proses penciptaan data yang tidak teridentifikasi, dan yang kemudian kita amati sebagai data historis. Terhadap data historis ini biasanya dilakukan penerapan ukuran-ukuran statistik, seperti mean, standard deviation, atau dilakukan regresi untuk mengestimasi berbagai jenis hubungan antar data series, yang kesemuanya disebut sebagai auxiliary model. Dengan asumsi bahwa GE model adalah proses penciptaan data yang benar, dalam arti merupakan 'model' yang digunakan oleh 'alam' dalam menghasilkan data historis, maka karakteristik data yang diperoleh dari GE model seharusnya akan menyerupai karakteristik data yang dihasilkan oleh auxiliary models.

\section{MEKANISME TRANSMISI DALAM GEMBI}

Dalam GEMBI, suatu kebijakan moneter mempengaruhi perkembangan di sisi internal (sektor riil dan pemerintah) dan di sisi eksternal (current account, nilai tukar, dan hutang luar negeri) melalui jalur transmisi suku bunga nominal dan jalur suku bunga riil. Secara lengkap, blok diagram untuk masing-masing sektor dan hubungannya satu sama lain adalah sebagai berikut:

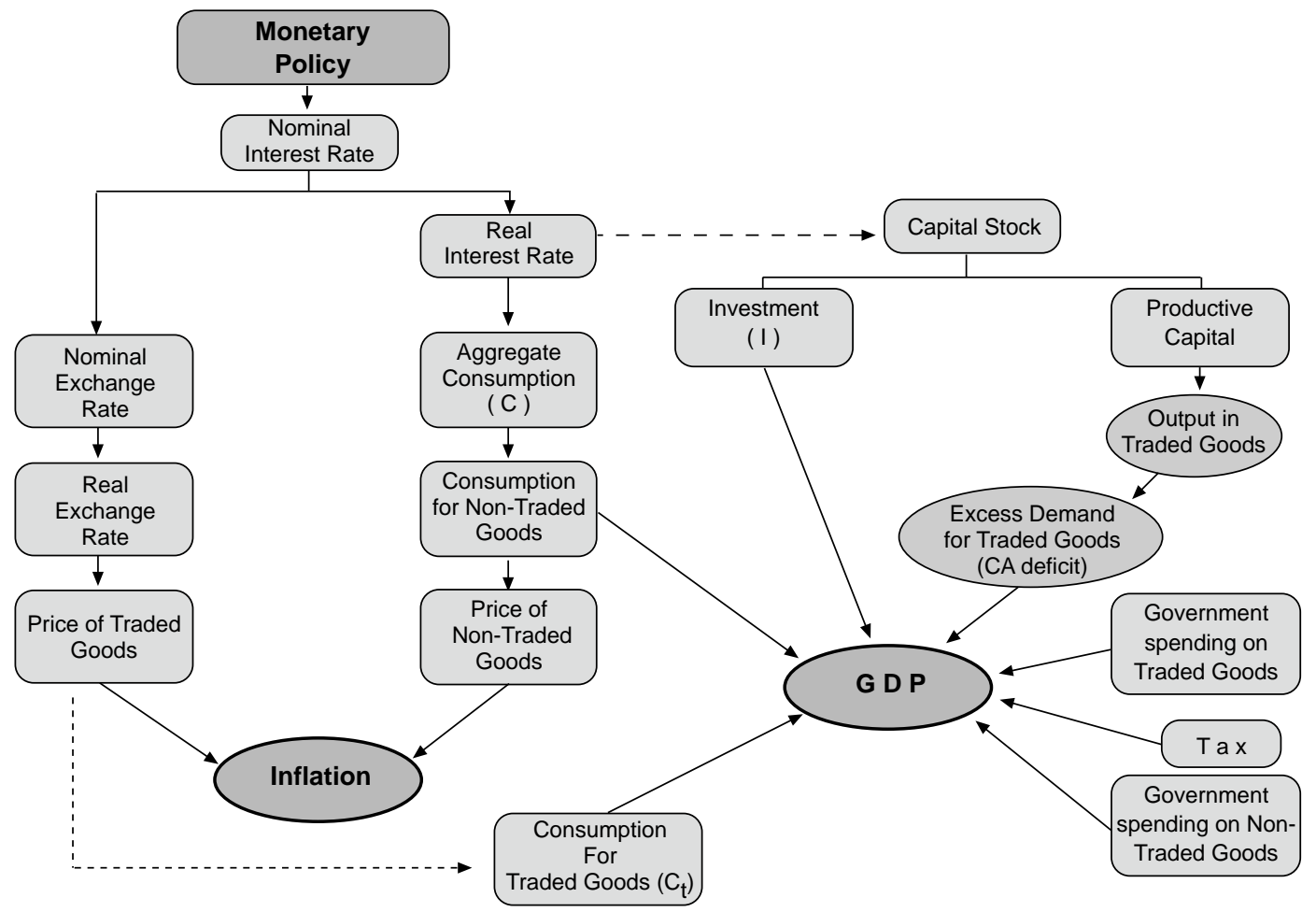


Suatu kebijakan moneter, misalnya otoritas moneter ingin melakukan pelonggaran dengan cara menambah stok money supply di masyarakat, akan mempengaruhi perkembangan konsumsi masyarakat, output dan inflasi melalui mekanisme sebagai berikut:

\section{A. Sisi Internal:}

\section{A.1. Jalur suku bunga nominal:}

Penambahan supply uang di masyarakat akan menurunkan suku bunga nominal, dan selanjutnya akan menurunkan suku bunga riil. Melalui intertemporal substitution effect, penurunan suku bunga riil tersebut akan meningkatkan aggregat consumption. Peningkatan aggregat consumption pada gilirannya akan menaikkan permintaan non traded goods, yang pada akhirnya akan menyebabkan kenaikan pada harga barang non traded goods. Meningkatnya permintaan terhadap barang non-tradables tersebut selanjutnya menimbulkan kenaikan excess demand pada sektor non-traded sehingga menimbulkan tekanan inflasi pada harga barang-barang non-tradables. Pada akhirnya inflasi pada sektor ini akan meningkatkan tekanan inflasi secara aggregat.

\section{A.2. Jalur sukubunga riil :}

Penambahan supply uang di masyarakat akan menurunkan suku bunga nominal dan suku bunga riil, yang selanjutnya melalui interest parity relation akan menyebabkan nilai tukar secara nominal terdepresiasi. Depresiasi nilai tukar ini akan menyebabkan peningkatan harga traded goods, yang secara langsung maupun tidak langsung menimbulkan tekanan inflasi. Besarnya pass-through effect dari depresiasi nilai tukar nominal ini akan tergantung pada share dari traded dan non-traded goods dalam suatu perekonomian.

Depresiasi nilai tukar secara riil juga akan mempengaruhi inflasi dalam negeri melalui dampaknya terhadap perubahan porsi konsumsi dari barang tradables ke barang-barang non-tradables akibat semakin mahalnya harga barang-barang tradables. Pengalihan konsumsi ini selanjutnya menimbulkan tekanan harga dalam sektor barang non-tradables akibat meningkatnya permintaan dan membesarnya excess-demand pada sektor tersebut. Sebagaimana pada A.1 di atas, membesarnya excess demand ini pada akhirnya akan menimbulkan tekanan inflasi secara aggregat.

Selain mempengaruhi inflasi, perubahan kebijakan moneter juga akan mempengaruhi GDP dan jumlah hutang pemerintah. GDP dalam model ini merupakan penjumlahan dari konsumsi di traded dan non-traded goods, investasi, pengeluaran pemerintah untuk traded dan non-traded goods, dikurangi dengan pajak dan excess demand. Dalam model ini excess demand didefinisikan sebagai penjumlahan dari konsumsi di traded goods, pengeluaran pemerintah untuk traded goods serta investasi, dikurangi dengan pajak dan output di traded 
goods. Sementara itu perkembangan hutang pemerintah (government bonds) merupakan respon pemerintah terhadap beban defisit anggaran yang dihadapinya.

\section{B. Sisi eksternal :}

Di sisi eksternal, perkembangan foreign liabilities ditentukan oleh perkembangan pada current account. Dalam model, perkembangan current account ini ditentukan oleh besarnya excess demand pada sektor tradables. Membesarnya excess demand pada sektor tradables berarti membesarnya current accout deficits yang perlu dibiayai. Dalam model pembiayaan ini sepenuhnya ditutup dari peningkatan hutang luar negeri, sehingga hutang luar negeri akan meningkat dengan membesarnya current account deficits.

\section{HASIL SIMULASI DAN EVALUASI KEBIJAKAN}

Sebagaimana telah dijelaskan pada Bab terdahulu, GEMBI memiliki kemampuan untuk melakukan simulasi kebijakan moneter (policy simulation $\mathcal{E}$ analysis) dan analisa dampak kebijakan terhadap besaran-besaran ekonomi (policy evaluation), serta menghasilkan lintasan dinamik (dynamic path) dari besaran-besaran makroekonomi seperti inflasi, suku bunga, nilai tukar nominal dan riil, PDB dan current account.

\section{A. Kalibrasi}

Sebelum menggunakan GEMBI untuk melakukan simulasi maupun evaluasi kebijakan, perlu dilakukan kalibrasi terhadap beberapa parameter penting dalam GEMBI yaitu besarnya parameter relative risk aversion $(\mathrm{h})$, social discount factor $(\mathrm{r})$, dan government expenditure on non-tradables $\left(\mathbf{g}_{\mathbf{n}}\right)$. Sebagai benchmark digunakan hasil proyeksi tahun 2000 dan 2001 dari MODBI untuk variabel-variabel pertumbuhan PDB, inflasi dan suku bunga nominal. Selanjutnya kalibrasi dilakukan dengan cara mengubah-ubah beberapa parameter tersebut di atas sehingga diperoleh keluaran yang sama/mendekati hasil proyeksi MODBI. Hasil kalibrasi tersebut adalah sebagai berikut:

\begin{tabular}{|l|r|r|r|r|}
\hline \multicolumn{1}{|c|}{ Variabel } & $\begin{array}{c}\text { MODBI } \\
\mathbf{2 0 0 0}\end{array}$ & $\begin{array}{c}\text { MODBI } \\
\mathbf{2 0 0 1}\end{array}$ & $\begin{array}{c}\text { GEMBI } \\
\mathbf{2 0 0 0}\end{array}$ & $\begin{array}{c}\text { GEMBI } \\
\mathbf{2 0 0 1}\end{array}$ \\
\hline GDP Growth & 4.2 & 4.5 & 4.67 & 4.90 \\
Inflasi & 8.9 & 7.9 & 10.14 & 7.43 \\
Interest Rate* & 12.5 & 13.0 & 10.41 & 10.64 \\
Exchange Rate & 8300 & 8000 & 8319 & 8287 \\
\hline Parameter & \multicolumn{1}{|c|}{$\rho=5$} & \multicolumn{1}{|c|}{$\mathrm{Gn}=4.0$} & $\mu=12.7 \%$ \\
\hline
\end{tabular}

* Suku bunga pada MODBI adalah suku bunga deposito 3 bulan. Pada GEMBI adalah suku bunga SBI 
Setelah diperoleh nilai parameter yang dianggap optimal, maka GEMBI siap digunakan untuk simulasi alternatif kebijakan maupun evaluasi kebijakan moneter. Simulasi bertujuan untuk melihat dynamic paths dari perekonomian untuk beberapa skenario (asumsi nilai variabel yang berbeda), sementara evaluasi bertujuan untuk memilih suatu kebijakan yang dinilai terbaik di antara beberapa alternatif kebijakan yang ada.

\section{B. Policy simulation}

\section{B.1. Simulasi Untuk Membandingkan Beberapa Skenario Ekonomi}

Simulasi bertujuan untuk melihat bagaimana perkembangan besaran-besaran perekonomian dalam jangka 3-5 tahun ke depan (2001 hingga 2005), untuk beberapa alternatif kebijakan moneter. Dalam hal ini kita ingin mengetahui bagaimana perkembangan besaran-besaran inflasi, interest rate, PDB dan nilai tukar 3-5 tahun ke depan (2001 hingga 2005) apabila kita menerapkan kebijakan pentargetan kuantitatif (Base Money Targeting). Simulasi dilakukan untuk 3 skenario berbeda, yaitu:

\begin{tabular}{|l|c|c|c|}
\hline & $\begin{array}{c}\text { Scenario A } \\
\text { (MODBI) }\end{array}$ & $\begin{array}{c}\text { Scenario B } \\
\text { (IMF) }\end{array}$ & $\begin{array}{c}\text { Scenario C } \\
\text { (ProgMon) }\end{array}$ \\
\hline GDP 2000 & $4.2 \%$ & $4.9 \%$ & $4.9 \%$ \\
$\boldsymbol{\pi}_{2000}$ & $8.9 \%$ & $5.8 \%$ & $5.8 \%$ \\
$\mathbf{i}_{2000}$ & $12.5 \%^{*}$ & $11 \%^{* *}$ & $11 \%^{* *}$ \\
$\mathbf{M O}_{\mathbf{2 0 0 1}}$ & $15.5 \%$ & $9,28 \%$ & $14.58 \%$ \\
\hline
\end{tabular}

Untuk setiap skenario, proyeksi nilai inflasi dan suku bunga tahun 2000 diberikan sebagai initial point bagi GEMBI. Untuk mendapatkan lintasan dinamik tahun 2001 hingga 2005, maka nilai proyeksi pertumbuhan uang primer untuk 2001 diberikan. Sebagai hasil running, diperoleh lintasan dinamik untuk masing-masing variabel sebagai berikut:

\section{a. Laju Inflasi}

Ketiga skenario menunjukkan penurunan inflasi dari initial point-nya ke dalam suatu rentang inflasi sebesar 3 - 5\% dalam periode 13 triwulan ke depan. Dalam jangka waktu lebih panjang, yaitu 50 triwulan ke depan, GEMBI juga memperlihatkan kecenderungan turunnya inflasi tersebut.

Dari tabel hasil terlihat bahwa laju inflasi untuk tahun 2001 yang dihasilkan oleh GEMBI (7,66\% dengan skenario MODBI, 6,70\% dengan skenario IMF, dan 6,74\% dengan skenario ProgMon) tidak jauh berbeda secara statistik dengan hasil proyeksi MODBI $(7,90 \%)$, IMF $(6.00 \%)$ dan ProgMon (6.00\%). Secara rata-rata, dalam tiga tahun ke depan laju inflasi adalah sebesar 6,44\% (dengan skenario MODBI) dan dalam lima tahun ke depan adalah sebesar $5,74 \%$. 


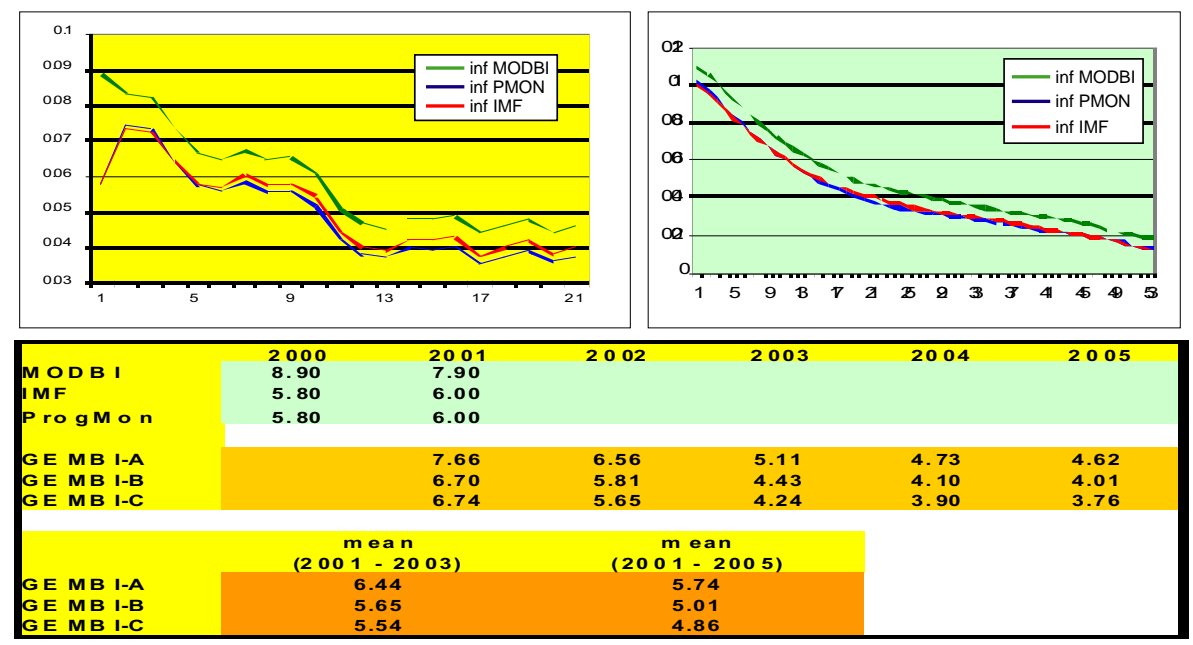

Pada simulasi dengan base money targeting ini, penurunan laju inflasi disebabkan oleh penyesuaian price level terhadap peningkatan konsumsi. Dari persamaan demand for money dapat dilihat bahwa peningkatan konsumsi akan meningkatkan permintaan akan uang. Namun demikian, karena pertumbuhan uang telah dipatok tetap maka variabel lain melakukan penyesuaian. Dalam hal ini, price level menyesuaikan ke bawah (turun) sehingga menurunkan laju inflasi secara keseluruhan. Variabel lainnya yg melakukan penyesuaian adalah suku bunga nominal yang bergerak naik.

\section{b. Suku Bunga}

Dari persamaan demand for money terlihat pula bahwa kenaikan konsumsi dalam kondisi pertumbuhan uang primer yang konstan akan berdampak juga kepada bergerak naiknya suku bunga nominal.

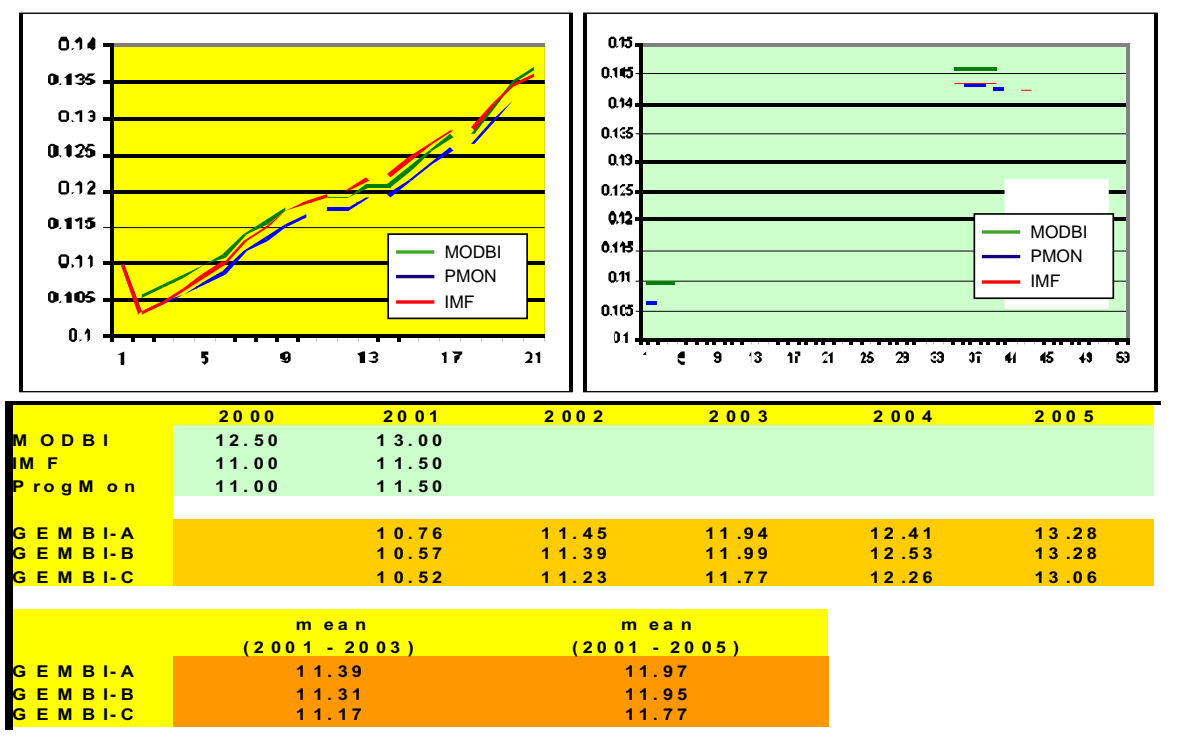


Dari tabel terlihat bahwa suku bunga nominal bergerak dari 10,76\% (untuk skenario MODBI) menjadi 11,94\% pada 2003 dan meningkat menjadi 13,28\% pada 2005. Secara ratarata besarnya suku bunga nominal dalam tiga tahun ke depan adaah 11,39\% dan untuk lima tahun ke depan sebesar 11,97\%. Secara riil, suku bunga juga menunjukkan lintasan yang meningkat, dan mencapai $8 \%$ dalam periode 3 tahun ke depan.

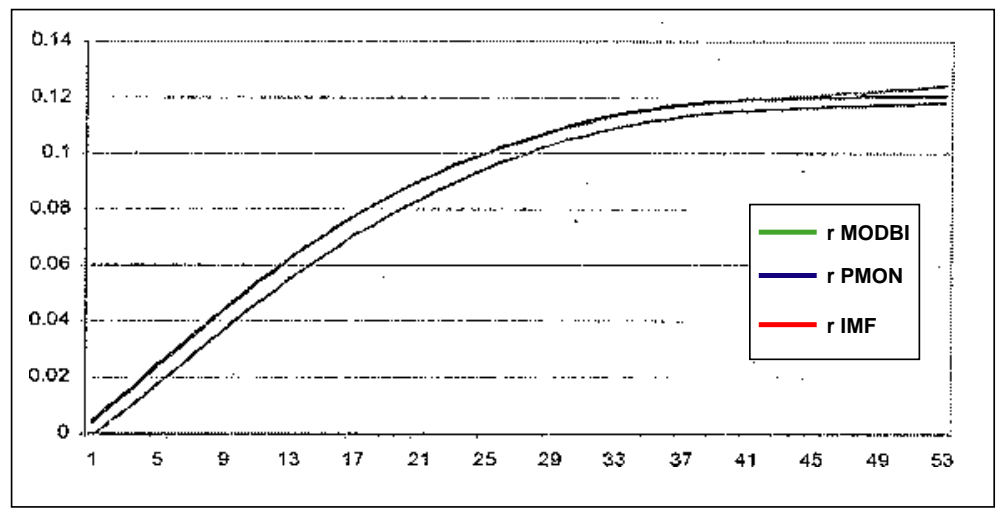

\section{c. Nilai Tukar Nominal}

Lintasan dinamik untuk nilai tukar nominal memperlihatkan perkembangan nilai tukar nominal yang relatif sabil. Pada skenario MODBI, misalnya, nilai tukar bergerak dari Rp8300 per USD menuju Rp8500 per USD, depresiasi sebesar Rp200, dalam jangka waktu 20 triwulan (3 tahun).

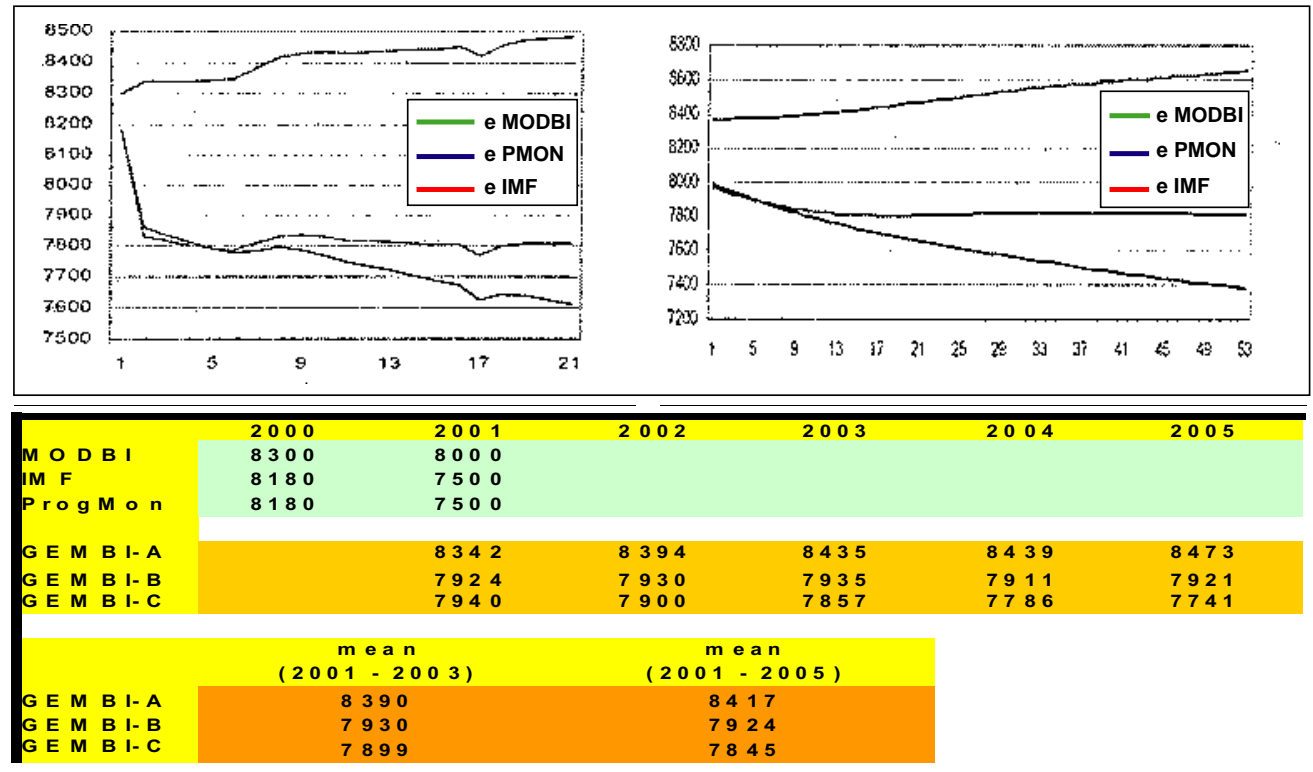


Secara rata-rata, nilai tukar nominal untuk masa 3 tahun ke depan adalah sebesar Rp8390 per USD, dan untuk masa 5 tahun ke depan sebesar Rp8417 per USD. Namun demikian, meskipun secara nominal pergerakan nilai tukar relatif stabil, secara riil terjadi penguatan (apresiasi) akibat meningkatnya suku bunga riil.

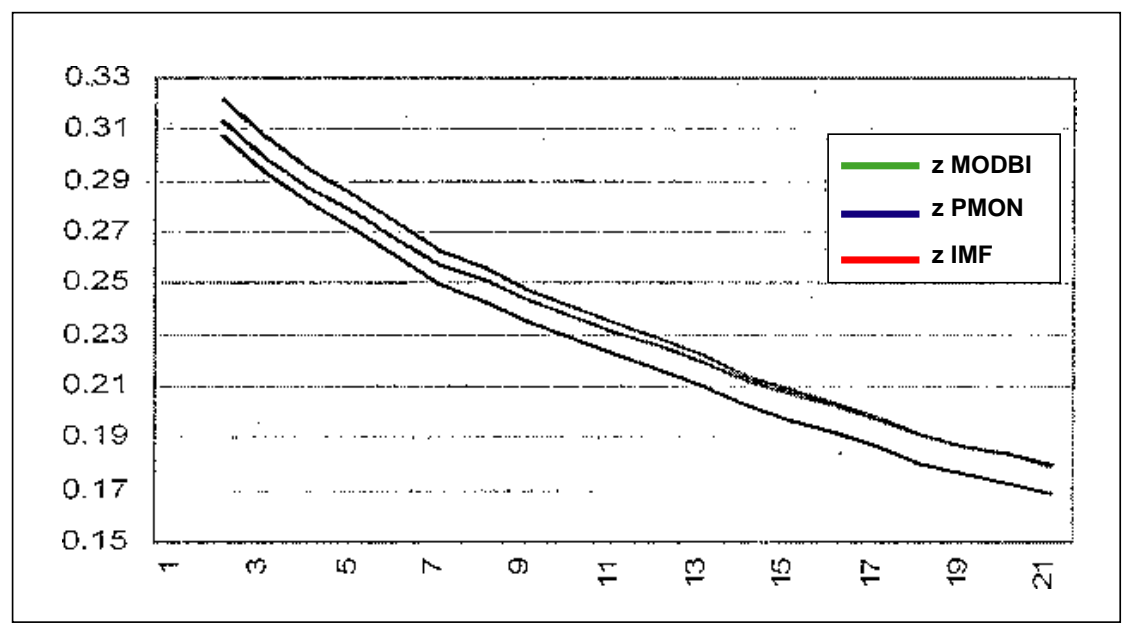

Di satu sisi, apresiasi nilai tukar secara riil ini menyebabkan harga barang-barang tradables menjadi lebih murah, sehingga konsumsi akan barang tradables ini meningkat. Peningkatan permintaan ini selanjutnya mendorong tingkat produksi di sektor industri tradables yang pada akhirnya memberi sumbangan terhadap kenaikan PDB.

Di sisi lain, peningkatan konsumsi akan barang-barang tradables berarti menurunnya konsumsi akan barang-barang non-tradables. Hal ini menyebabkan turunnya excess demand di sektor non-traded yang menghasilkan penurunan tekanan harga barang non-traded. Dari persamaan inflasi, deflasi pada sektor barang non-traded inilah yang juga menurunkan laju inflasi.

\section{d. Pertumbuhan Ekonomi (PDB)}

Di samping adanya kenaikan produksi pada sektor tradables, peningkatan suku bunga riil juga memberikan kontribusi positif terhadap pertumbuhan PDB melalui peningkatan konsumsi. Meningkatnya suku bunga riil akibat penurunan laju inflasi menyebabkan nilai ekspektasi konsumsi $\left(\mathbf{C}_{\mathbf{t}+1}\right)$ terus meningkat yang akhirnya mendorong naik konsumsi inthe-long-run secara keseluruhan.

Dengan kata lain "wealth effect on consumption" dari kenaikan real return dalam GEMBI adalah lebih besar dibandingkan dengan "substitution effect from consumption to savings" dari peningkatan suku bunga nominal. 


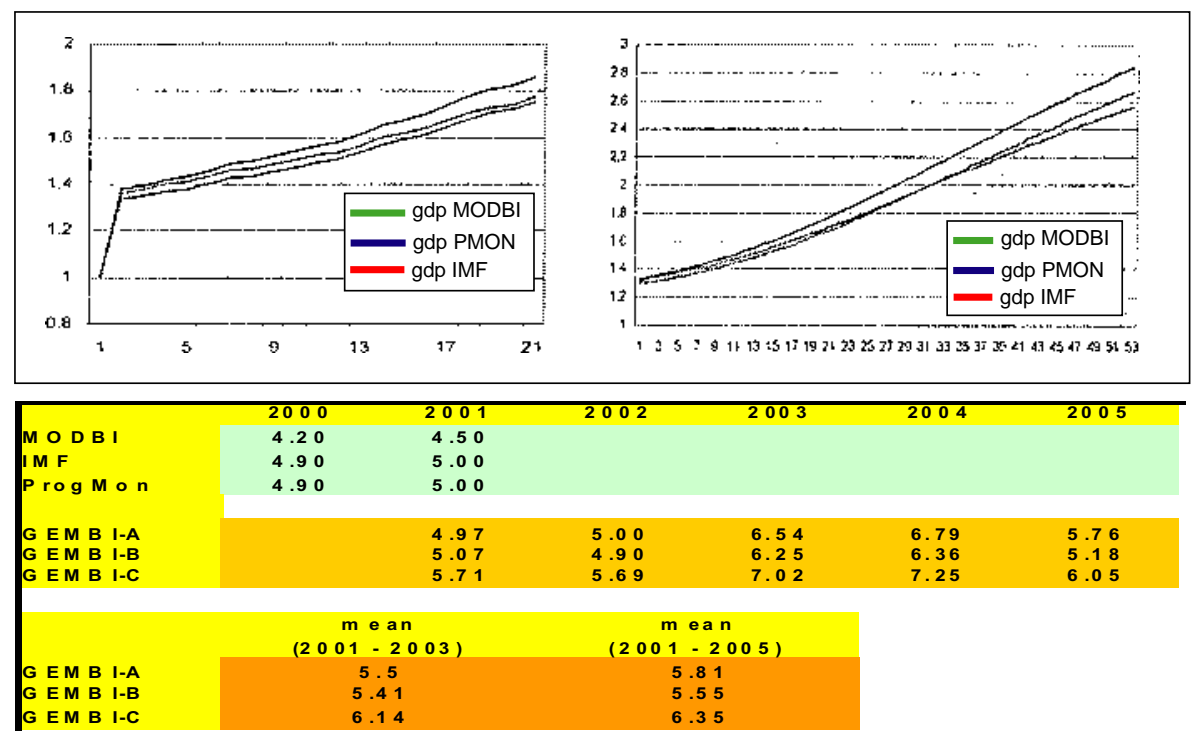

\section{B.2. Simulasi Untuk Membandingkan Beberapa Monetary Frameworks}

Pada bagian ini akan dikemukakan hasil simulasi GEMBI untuk membandingkan lintasan dinamik perekonomian dengan 2 monetary frameworks yang berbeda: Base Money Targeting dan Interest Rate Targeting. Sebagai angka inflasi inisial digunakan angka MODBI, yaitu inflasi sebesar $8,9 \%$.

Dengan Base Money Targeting otoritas moneter mematok besarnya pertumbuhan tahunan Base Money (M0) pada nilai tertentu, yang dalam hal ini adalah sebesar 15,5\% per tahun. Dan besarnya suku bunga nominal yang terjadi ditentukan secara endogenous oleh model.

Sebaliknya dengan Interest Rate Targeting, otoritas moneter mematok nilai suku bunga nominal pada suatu nilai tertentu, yang dalam hal ini sebesar $12 \%$. Sementara besarnya uang beredar yang terjadi ditentukan secara endogenous oleh model.

\section{a. Laju Inflasi}

Dari grafik terlihat bahwa kedua monetary frameworks menghasilkan penurunan laju inflasi dari 8,9\% ke dalam rentang inflasi sebesar 4\% - 5\% dalam waktu 3 tahun. Terlihat bahwa penurunan inflasi pada Base Money Targeting lebih cepat dibandingkan dengan pada Interest Rate Targeting.

Pada Base money targeting, inflasi turun secara cepat akibat penurunan price level sebagai suatu adjustment terhadap kenaikan konsumsi. Sementara itu, pada interest rate targeting terlihat inflasi meningkat dulu hingga mencapai $11 \%$ pada triwulan ketiga. Hal ini 


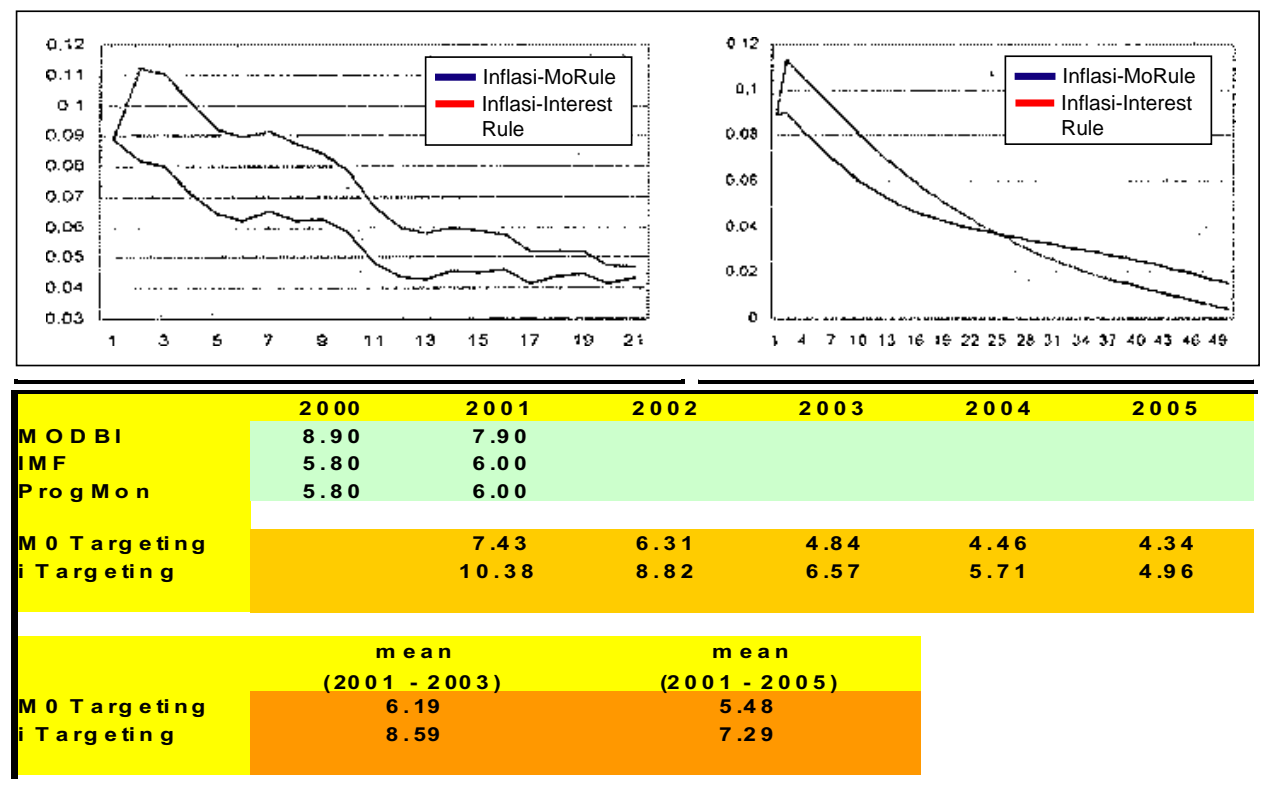

disebabkan oleh sifat inflatoir dari peningkatan money supply yang mengakomodasi peningkatan konsumsi.

Pada interest rate targeting, mekanisme penurunan inflasi adalah melalui jalur perubahan nilai tukar riil dan porsi konsumsi antara barang tradables dan non-tradables. Meskipun suku bunga nominal dipatok konstan sebesar $12 \%$, tetapi secara riil suku bunga mengalami peningkatan dari 1\% menjadi $8 \%$ dalam waktu 3 tahun. Hal ini menyebabkan terapresiasi nilai tukar secara riil. Apresiasi nilai tukar riil ini menyebabkan harga barangbarang tradables menjadi lebih murah sehingga permintaan terhadap barang-barang tradables
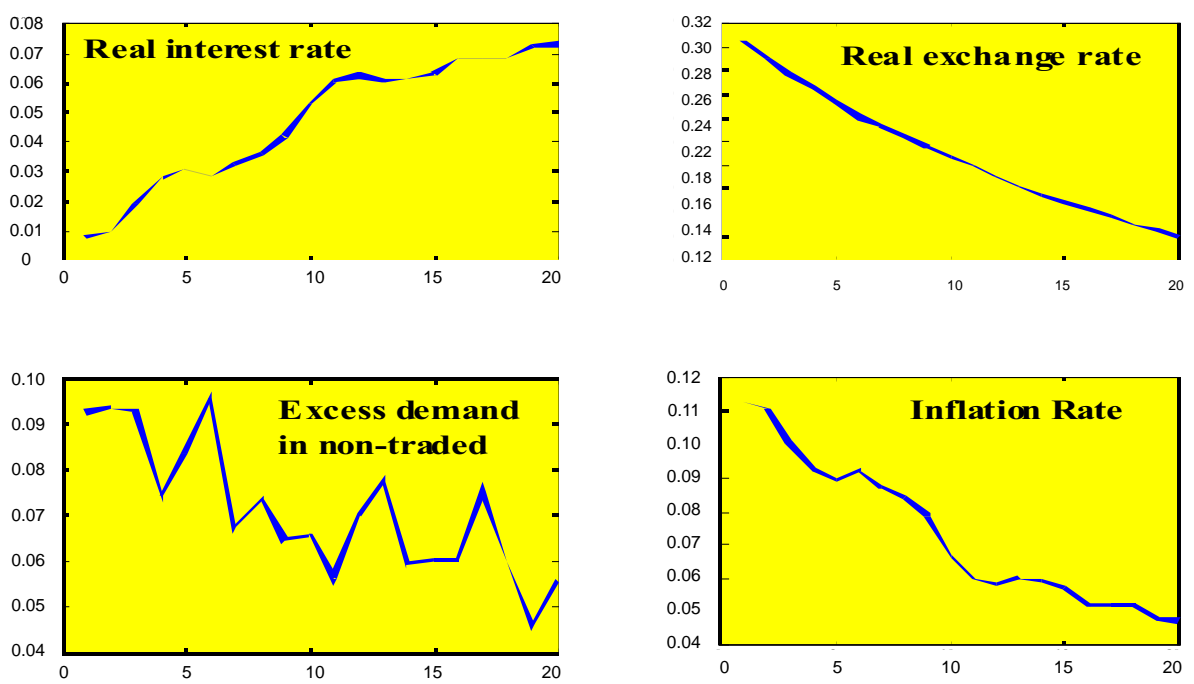
meningkat. Pada saat yang bersamaan porsi konsumsi untuk barang-barang non-tradables berkurang, sehingga terjadi penurunan excess demand pada sektor non-traded. Berkurangnya permintaan terhadap barang-barang non-traded selanjutnya mendorong penurunan harga dan pada akhirnya menurunkan laju inflasi secara keseluruhan.

\section{b. Suku Bunga}

Adapun lintasan dinamik untuk suku bunga nominal adalah sebagai berikut:

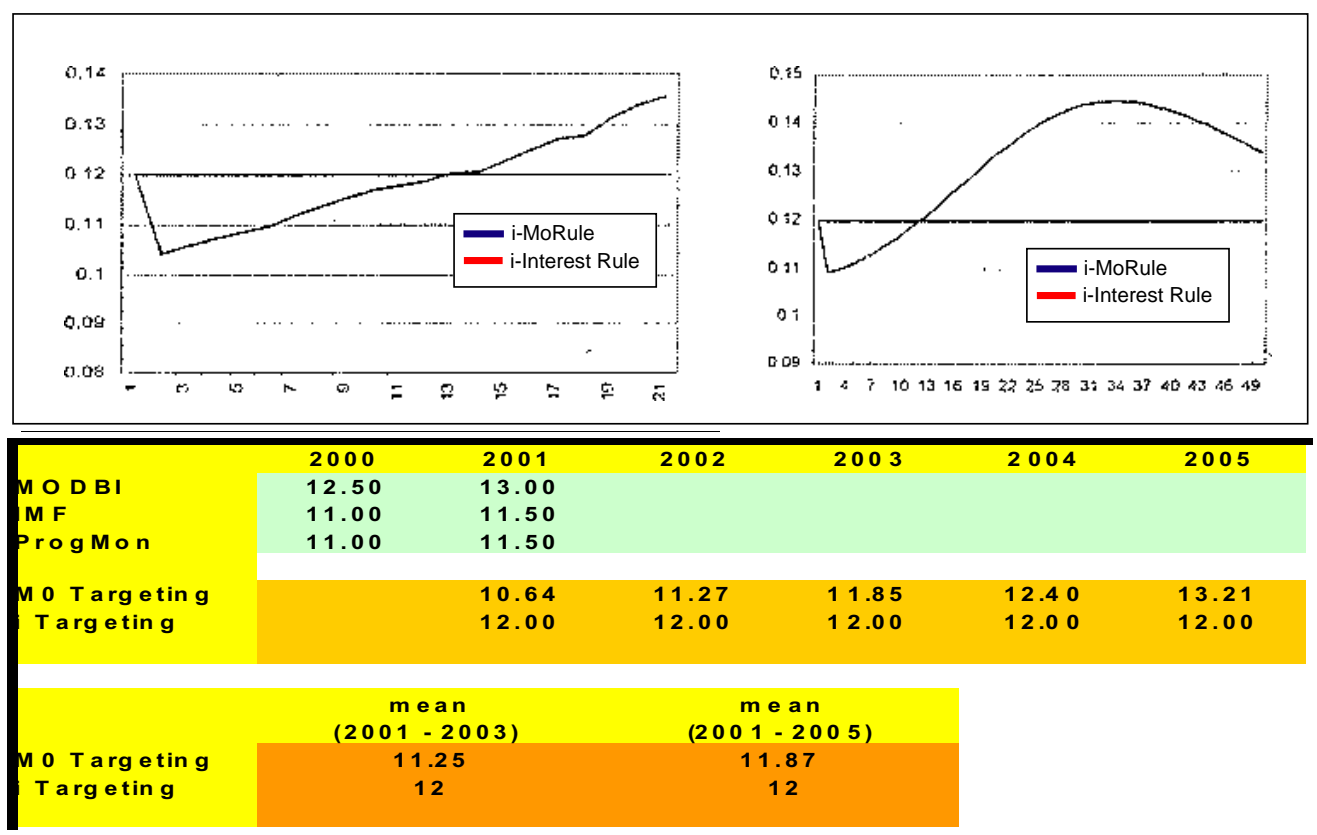

Secara nominal, suku bunga cenderung bergerak naik dari $11 \%$ menjadi $13 \%$ dalam waktu 3 tahun ke depan pada base money targeting hingga 6 tahun ke depan untuk kemudian bergerak turun.

\section{c. Nilai Tukar Nominal}

Pada base money targeting, pergerakan nilai tukar nominal relatif stabil dalam rentang Rp8200 - Rp8400 per USD dalam waktu 3 tahun ke depan. Sementara itu pada interest targeting pergerakan nilai tukar nominal terlihat terdepresiasi terlebih dahulu ("overshooting") sampai dengan triwulan ke-8, untuk kemudian menguat secara persisten.

Secara rata-rata dalam periode 3 tahun ke depan, nilai tukar nominal berada pada Rp8322 per USD untuk base money targeting dan pada Rp8832 per USD untuk interest rate targeting. 


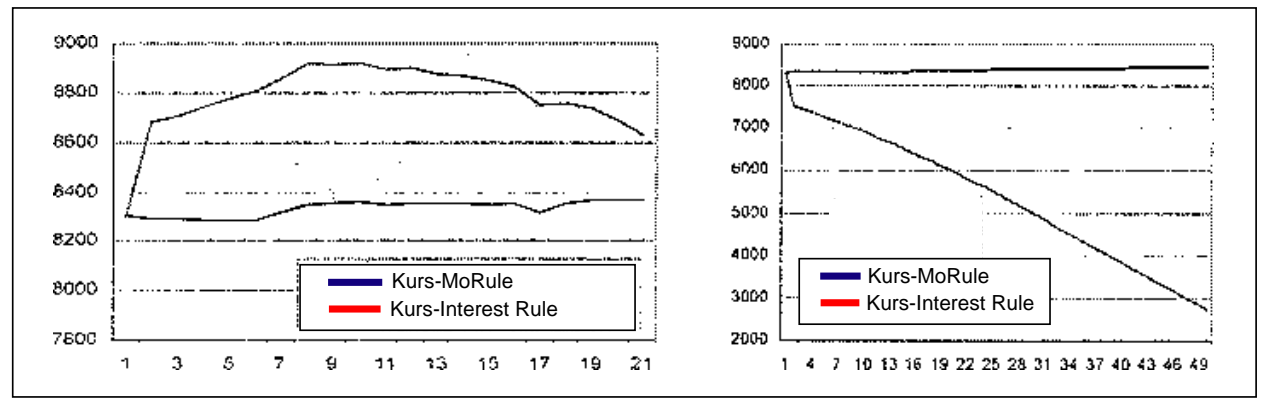

\begin{tabular}{|lllllll}
\hline MO D B I & 2000 & 2001 & 2002 & 2003 & 2004 & 2005 \\
IM F & 8300 & 8000 & & & & \\
P rog Mon & 8180 & 7500 & & & & \\
M O Targeting & 8180 & 7500 & & & & \\
i T argeting & & 8287 & 8326 & 8353 & 8343 & 8362 \\
& & 8725 & 8873 & 8897 & 8824 & 8703 \\
\hline
\end{tabular}

m e a $\mathrm{n}$

$(2001-2003)$

8322

8832 m ea $\mathbf{n}$

(2001- 2005$)$

8322

8804

\section{d. Pertumbuhan Ekonomi (PDB)}

Hasil simulasi memperlihatkan bahwa meski kedua monetary framework menghasilkan positive GDP growth rate, pertumbuhan ekonomi dengan base money targeting lebih cepat dibandingkan dengan pertumbuhan ekonomi dengan interest rate targeting.

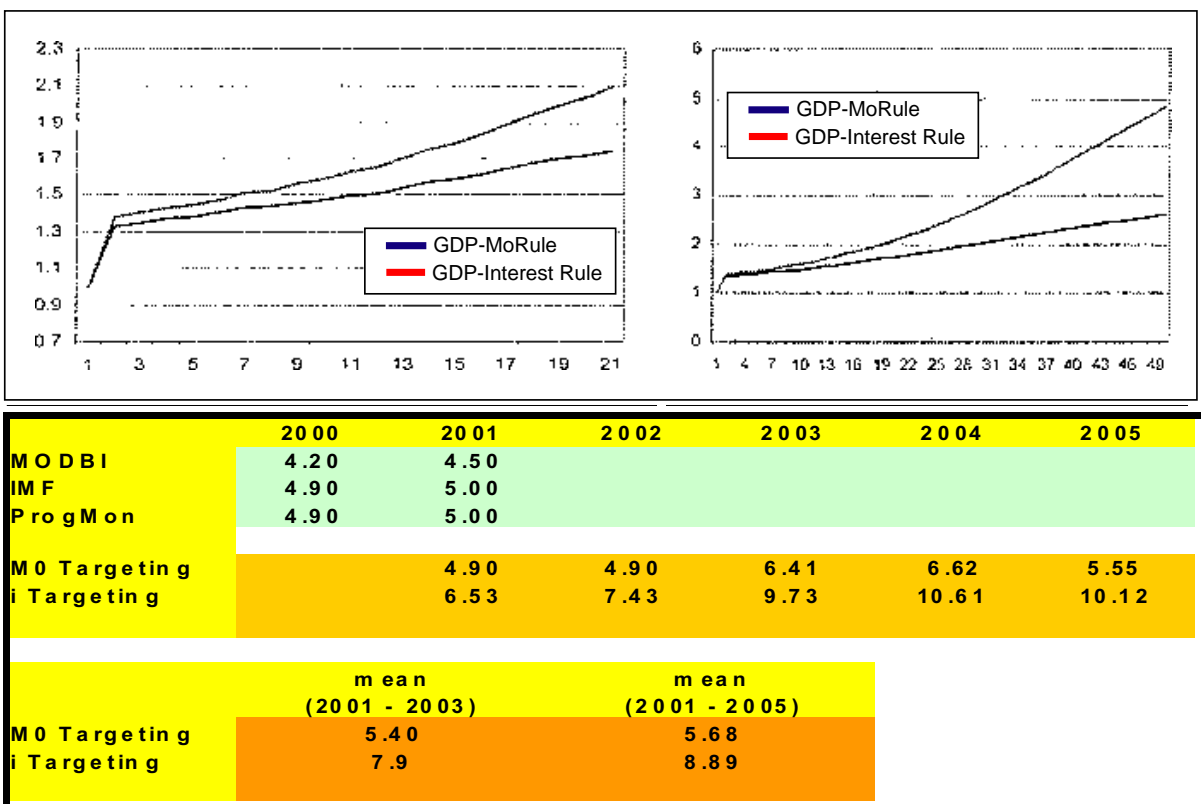


Perbedaan ini dinilai disebabkan oleh lebih rendahnya suku bunga nominal pada base money targeting sejak awal triwulan hingga triwulan ke-13. Rendahnya suku bunga ini memberikan stimulus yang lebih besar kepada pertumbuhan ekonomi selama periode tersebut.

\section{B.3. Simulasi Pencapaian Target Inflasi}

Dalam bagian ini akan ditunjukkan bagaimana suatu kebijakan moneter dengan base money targeting framework menghasilkan dynamic path dari inflasi. Lintasan dinamik ini selanjutnya dibandingkan dengan lintasan proyeksi yang dihasilkan oleh suatu model makroekonometrik untuk inflation forecasting yang dibuat oleh Bagian Studi Sektor Riil (SSR). Suatu target inflasi sebesar 5\% ditetapkan untuk dicapai dalam waktu 3 dan 5 tahun ke depan.

Grafik pertama memperlihatkan lintasan dinamik inflasi untuk suatu base money targeting dengan pertumbuhan base money dipatok sebesar 15,5\%. Terlihat bahwa dalam waktu 12 triwulan ke depan ( 3 tahun) laju inflasi mencapai level sedikit di bawah 5\%, dan lintasan dinamik yang dihasilkan oleh GEMBI tampak sejalan dengan yang dihasilkan oleh model SSR.

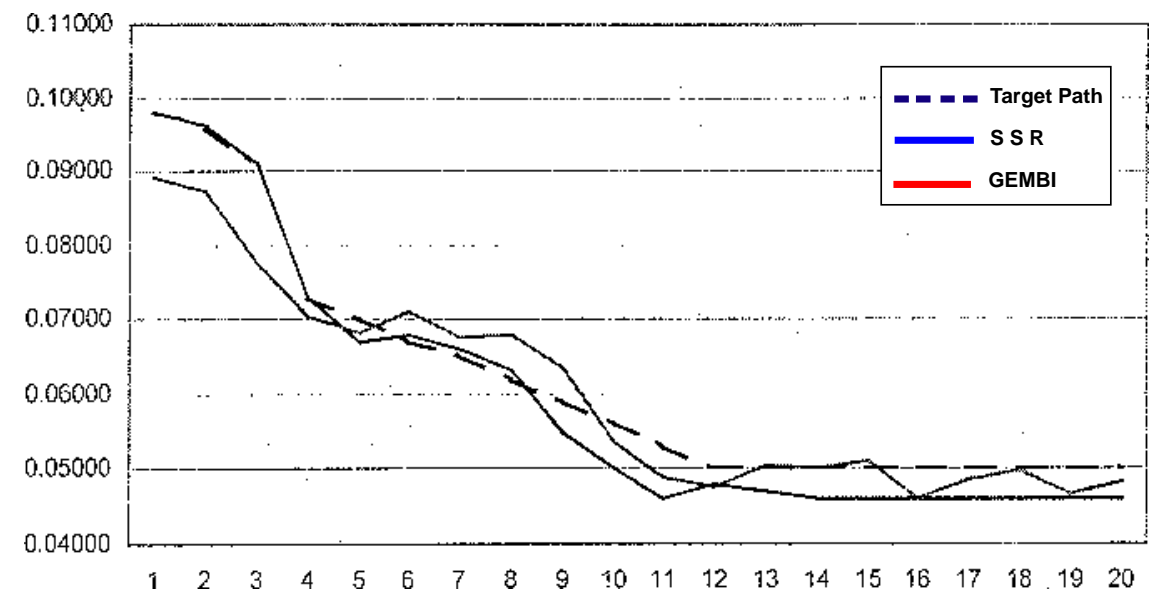

Secara rata-rata, laju inflasi untuk setiap tahunnya sejak 2001 hingga 2005 adalah sebagaimana tercantum dalam tabel berikut ini:

\begin{tabular}{|l|c|c|c|c|c|}
\hline & 2001 & 2002 & 2003 & 2004 & 2005 \\
\hline SSR & 8.95 & 6.60 & 4.98 & 4.63 & 4.60 \\
GEMBI & 8.11 & 6.87 & 5.33 & 4.94 & 4.83 \\
\hline
\end{tabular}


Grafik kedua di bawah ini memperlihatkan lintasan dinamik inflasi untuk base money targeting dengan laju pertumbuhan base money yang dipatok sebesar $20 \%$.

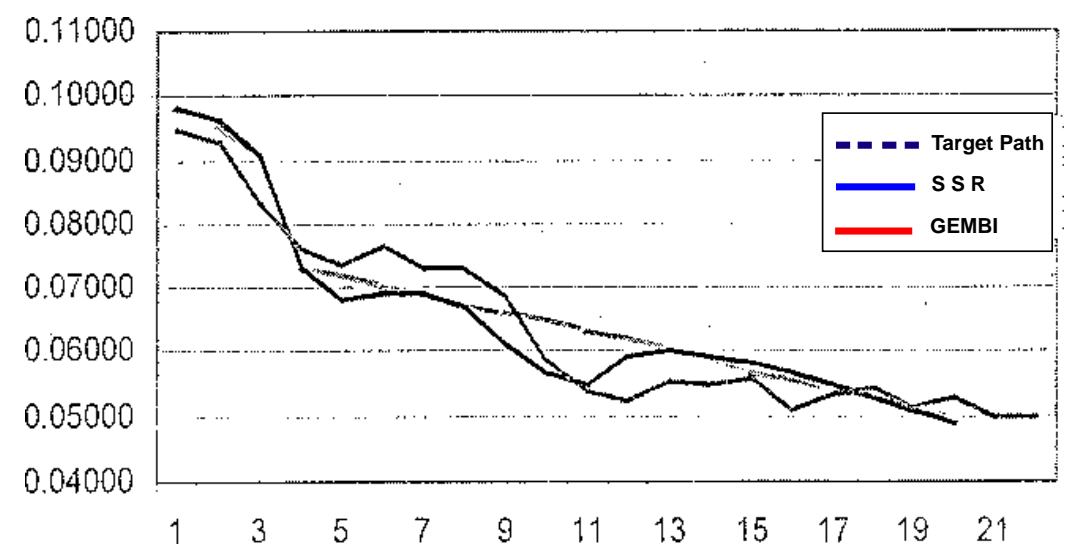

Terlihat bahwa laju inflasi mencapai 5\% setelah 21 triwulan ke depan, dan lintasan dinamik yang dihasilkan oleh GEMBI sejalan dengan yang dihasilkan oleh model SSR. Secara rata-rata, laju inflasi setiap tahunnya dari 2001 hingga 2005 adalah sebagai berikut:

\begin{tabular}{|l|c|c|c|c|c|}
\hline & 2001 & 2002 & 2003 & 2004 & 2005 \\
\hline SSR & 8.95 & 6.83 & 5.80 & 5.85 & 5.20 \\
GEMBI & 8.67 & 7.40 & 5.83 & 5.43 & 5.30 \\
\hline
\end{tabular}

\section{Policy Evaluation}

\section{C.1. Beberapa Skenario Base Money Targeting}

Pada bagian ini akan dilakukan penilaian tentang skenario mana yang "terbaik" di antara ketiga skenario (MODBI, IMF, dan Program Moneter) yang telah disimulasikan pada bagian B.1. terdahulu. Sebelum melakukan evaluasi, initial points untuk ketiga skenario dimaksud harus disamakan terlebih dahulu, kecuali untuk variabel pertumbuhan base money, yaitu:

\begin{tabular}{|l|c|c|c|}
\hline & $\begin{array}{c}\text { Scenario A } \\
\text { (MODBI) }\end{array}$ & $\begin{array}{c}\text { Scenario B } \\
\text { (IMF) }\end{array}$ & $\begin{array}{c}\text { Scenario C } \\
\text { (ProgMon) }\end{array}$ \\
\hline GDP 2000 & $4.2 \%$ & $4.2 \%$ & $4.2 \%$ \\
$\boldsymbol{\pi}_{2000}$ & $8.9 \%$ & $8.9 \%$ & $8.9 \%$ \\
$\mathbf{i}_{2000}$ & $12 \%$ & $12 \% \%^{* *}$ & $12 \%{ }^{* *}$ \\
$\mathbf{M O}_{\mathbf{2 0 0 1}}$ & $15.5 \%$ & $9.28 \%$ & $14.58 \%$ \\
\hline
\end{tabular}


Dari hasil simulasi GEMBI, terlihat bahwa untuk hampir semua variabel ekonomi kecuali nilai tukar nominal ketiganya memberikan lintasan dinamik yang mirip.

\section{a. Laju Inflasi}

Untuk semua nilai pertumbuhan base money, terlihat laju inflasi turun dari nilai inisialnya $(8,9 \%)$ ke dalam suatu rentang inflasi sebesar $4 \%$ - 5\% dalam jangka waktu 12 triwulan (3 tahun).

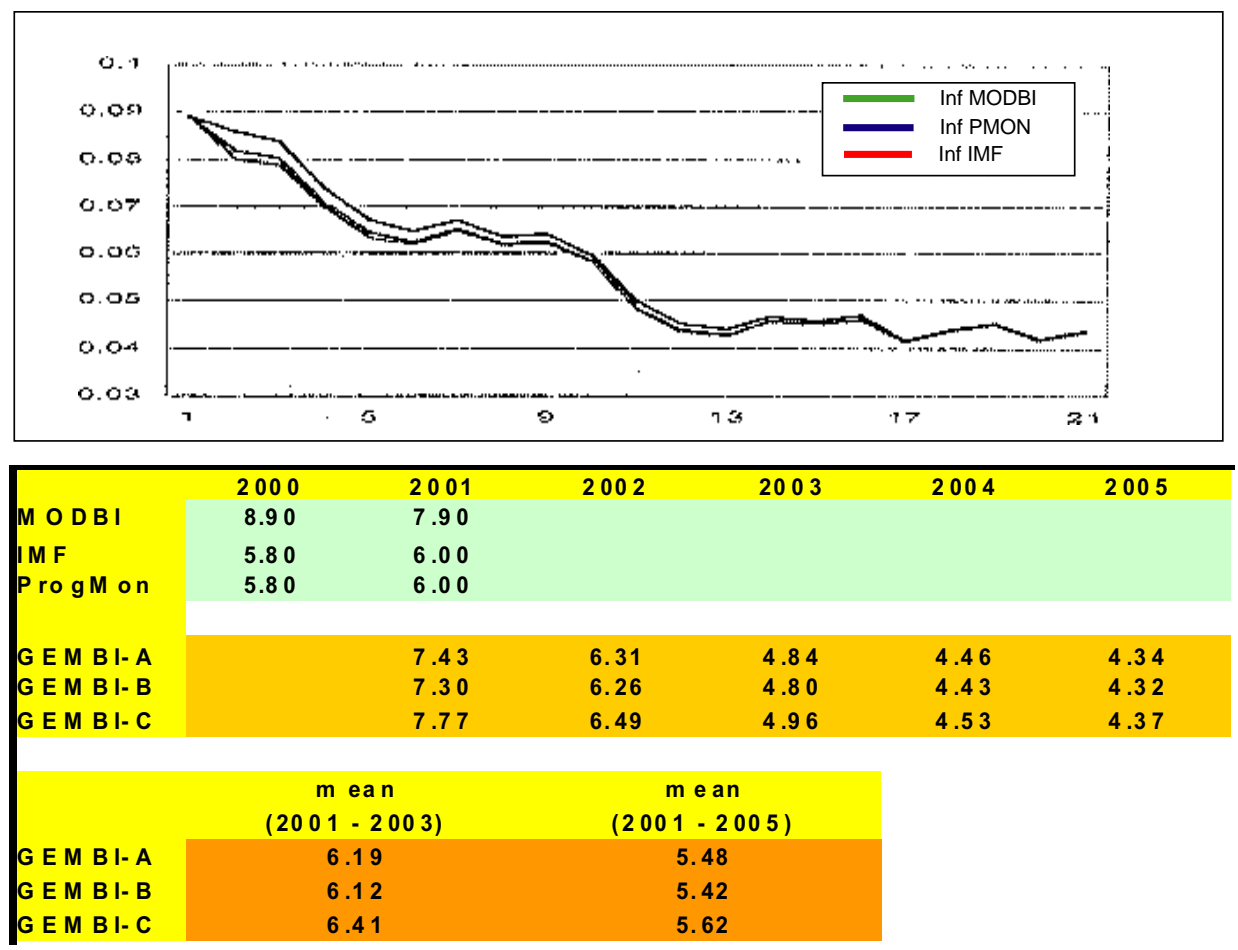

Secara rata-rata, laju inflasi untuk tiga tahun ke depan adalah sebesar 6,19\% (M0 growth=15,5\%), 6,12\% (M0 growth=9,28\%), dan 6,41\% (M0 growth=14,58\%). Untuk lima tahun ke depan, laju inflasi rata-rata adalah berturut-turut sebesar 5,48\%, 5,42\% dan $5,62 \%$.

\section{b. Suku Bunga Nominal}

Suku bunga nominal untuk ketiga skenario juga memperlihatkan kecenderungan yang sama, yaitu meningkat dari sekitar 10\% mencapai 13,5\% pada tahun kelima. Secara ratarata, suku bunga nominal untuk tiga tahun ke depan adalah sebesar 11,25\% (skenario MODBI), 11,50\% (skenario IMF), dan 11,40\%(skenario Program Moneter). 


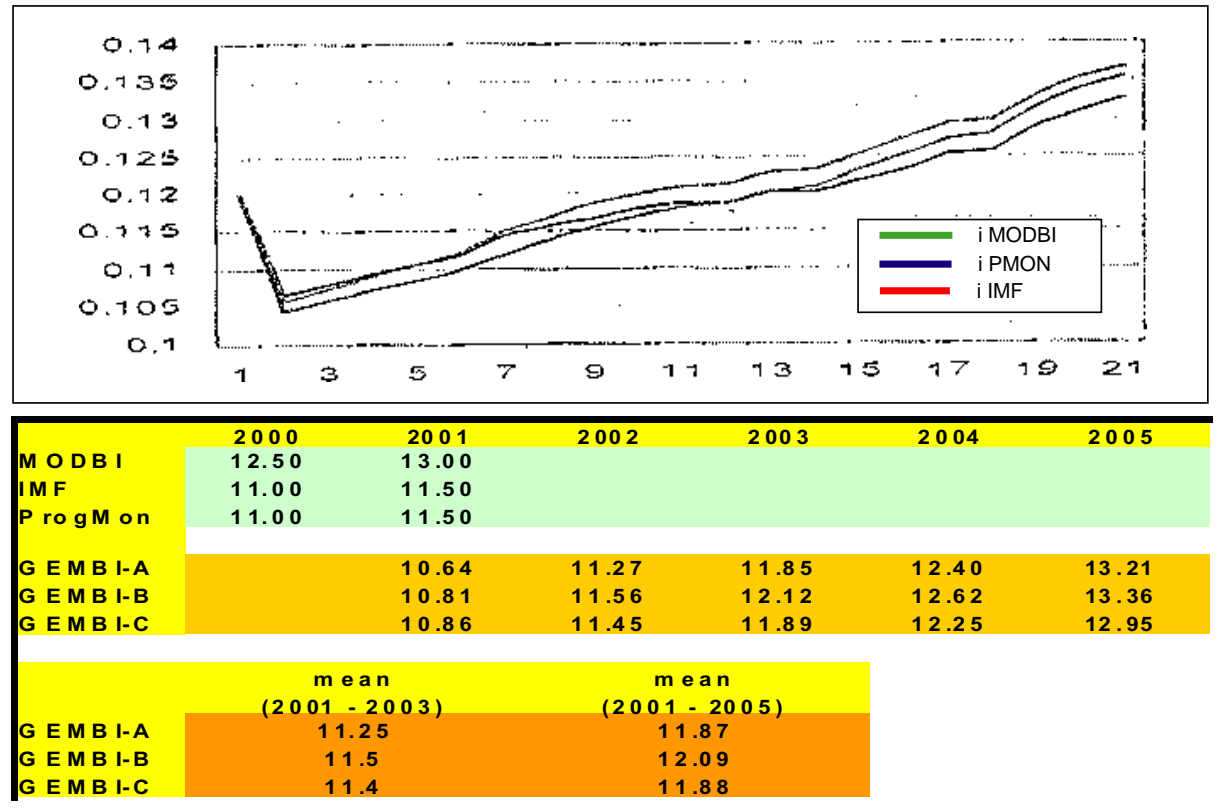

\section{c. Nilai Tukar Nominal}

Perkembangan nilai tukar secara nominal juga menunjukkan pergerakan yang relatif stabil untuk jangka panjang. Namun demikian skenario Program Moneter dengan pertumbuhan base money yang relatif tinggi menghasilkan nilai tukar yang lebih lemah,

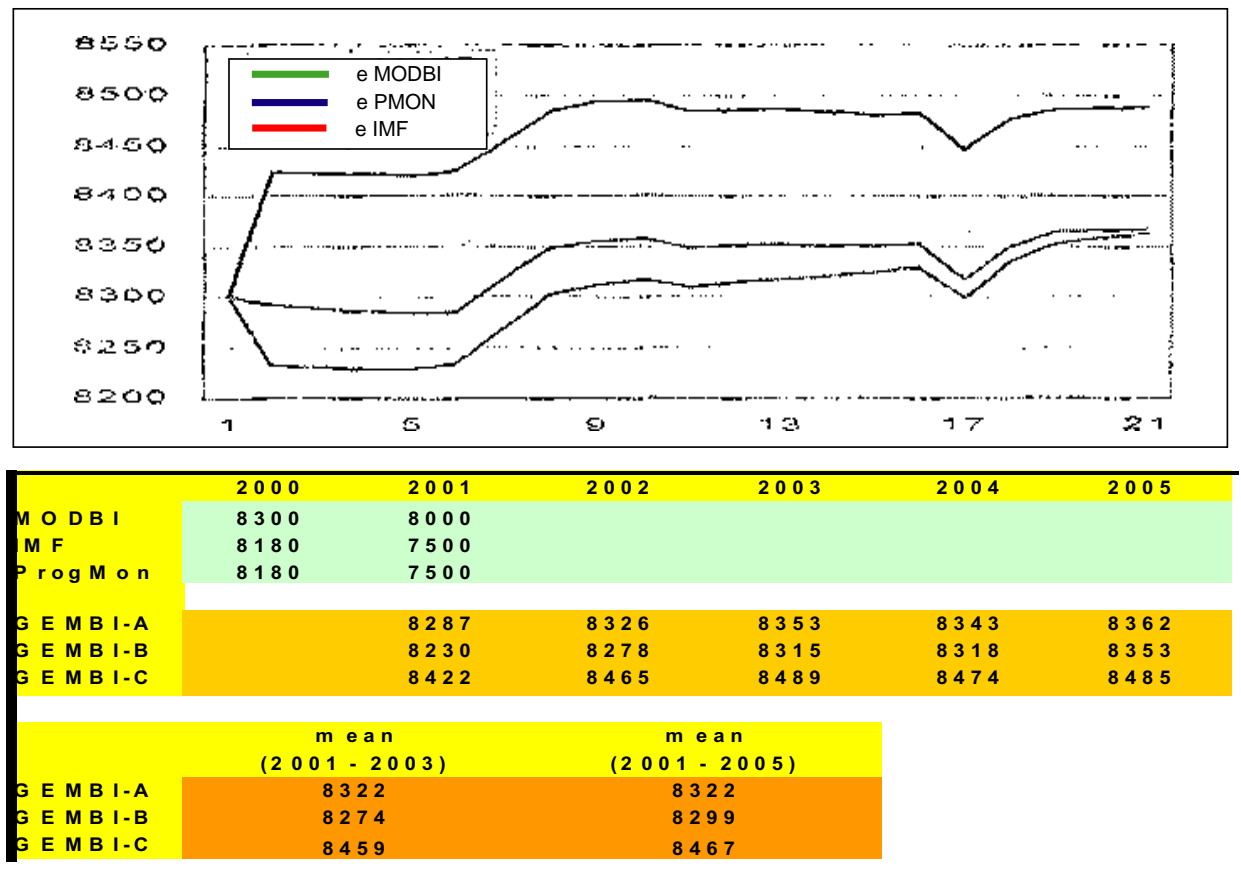


dengan rata-rata tiga tahun ke depan sebesar Rp8459 per USD. Sementara itu untuk skenario MODBI dan IMF nilai tukar rata-rata 3 tahun ke depan adalah sebesar Rp8322 per USD dan Rp8247 per USD.

\section{d. Pertumbuhan Ekonomi (PDB)}

Ketiga skenario juga menunjukkan lintasan dinamik dari PDB yang hampir sama, dengan kecenderungan untuk terus meningkat.

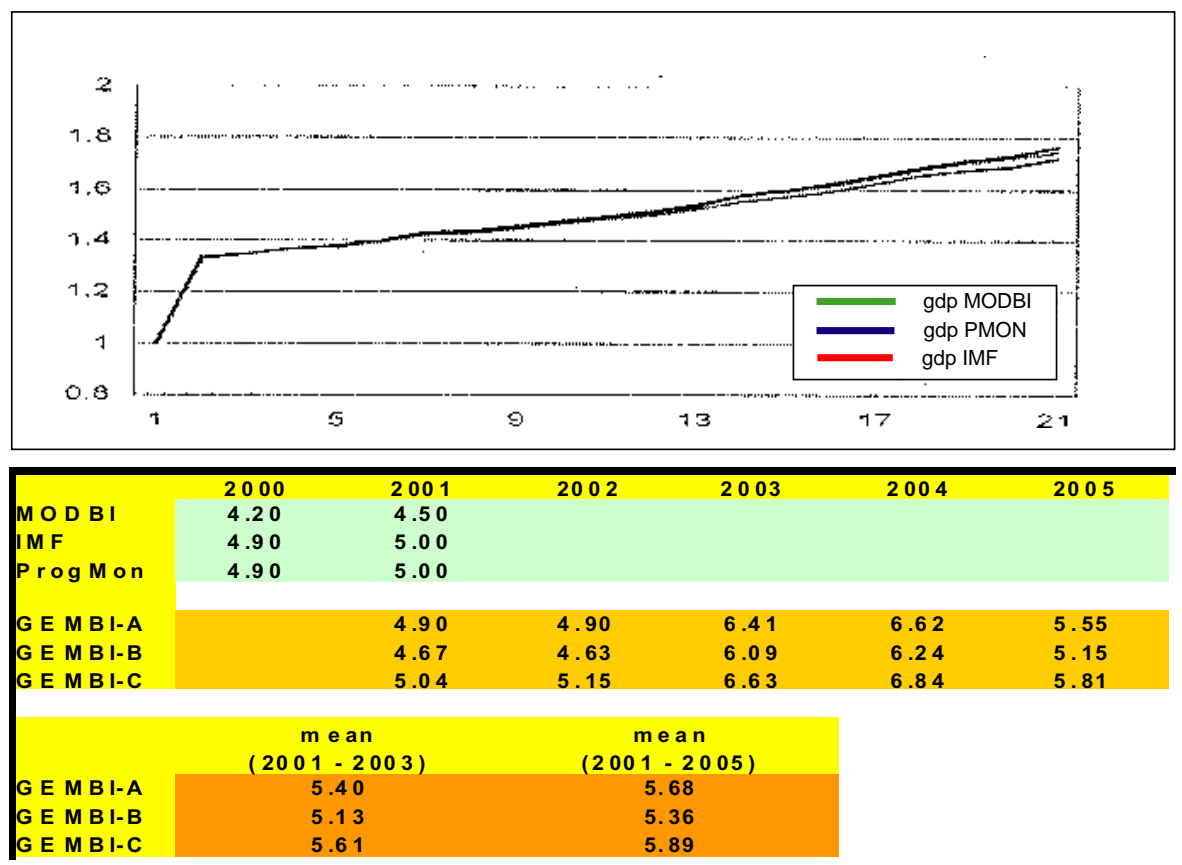

Secara rata-rata, pertumbuhan PDB untuk 3 tahun ke depan adalah 5,40\%(skenario MODBI), 5,13\%(skenario IMF), dan 5,61\%(skenario Program Moneter).

Sebagai kesimpulan, maka diperoleh tabel berikut ini untuk melakukan perbandingan nilai rata-rata baik untuk laju inflasi yang dihasilkan, suku bunga nominal, nilai tukar nominal, dan pertumbuhan PDB sebagai berikut:

\begin{tabular}{|c|c|c|c|c|}
\hline \multicolumn{5}{|c|}{$2001-2003$} \\
\hline & Inflation & Exch. Rate & GDP & Int. Rates \\
\hline GEMBI-A & 6.19 & 8322 & 5.40 & 11.25 \\
GEMBI-B & 6.12 & 8274 & 5.13 & 11.50 \\
GEMBI-C & 6.41 & 8459 & 5.61 & 11.40 \\
\hline
\end{tabular}

\begin{tabular}{|c|c|c|c|c|}
\hline \multicolumn{5}{|c|}{$2001-2005$} \\
\hline & Inflation & Exch. Rate & GDP & Int. Rates \\
\hline GEMBI-A & 5.48 & 8322 & 5.68 & 11.87 \\
GEMBI-B & 5.42 & 8299 & 5.36 & 12.09 \\
GEMBI-C & 5.62 & 8267 & 5.89 & 11.88 \\
\hline
\end{tabular}


Mana skenario yang "terbaik" adalah sangat tergantung kepada bagaimana preferensi dari pengambil kebijakan. Apabila policy maker lebih menitikberatkan kepada pertumbuhan ekonomi yang tinggi, maka skenario Program Moneter (M0 growth=14,58\%) dapat menjadi pilihan. Apabila lebih diinginkan untuk memiliki nilai tukar yang lebih kuat dan inflasi yang lebih rendah, maka skenario IMF (M0 growth=9,28\%) menjadi pilihan. Untuk kebijakan yang lebih moderate, maka skenario MODBI $(\mathrm{M} 0=15,50 \%)$ lebih disukai.

\section{Arah Pengembangan Model}

Serangkaian diskusi dan presentasi telah dilakukan oleh Tim GEMBI, baik di lingkungan DKM maupun di luar Bank Indonesia (the Reserves Bank of New Zealand dan Keio University-Jepang) ${ }^{1}$. Dari kegiatan tersebut diperoleh banyak masukan baik mengenai struktur model GEMBI maupun terhadap hasil-hasil simulasinya. Tim GEMBI sendiri terus melakukan evaluasi terhadap kinerja model dan telah diidentifikasi aspek-aspek yang perlu ditambahkan ke dalam model atau dikembangkan/disempurnakan dalam tahap pengembangan model selanjutnya.

Secara umum GEMBI telah memiliki struktur yang cukup baik, yang telah meliputi hampir semua aspek penting dalam perekonomian. Meskipun demikian, struktur yang ada masih perlu dipertajam sehingga lebih mampu mencerminkan struktur perekonomian sebenarnya.

\section{A. Sektor Produksi}

Sektor produksi barang non-tradables $\left(\mathbf{y}_{\mathbf{n}}\right)$ akan dipertajam dengan memasukkan secara eksplisit fungsi produksi yang melibatkan productive capital untuk barang non-traded, sebagaimana telah dilakukan untuk sektor produksi barang tradables. Hal ini akan memungkinkan dimasukkannya "time-to-build constraint" pada persamaan pembentukan productive capital serta penghitungan output gap dalam persamaan investasi di sektor nontraded ini.

Selanjutnya penyempurnaan dimaksud akan membuat faktor excess demand pada sektor non-traded menjadi lebih realistis untuk menangkap munculnya tekanan inflasi dari permintaan agregat terhadap barang-barang non-traded.

\section{B. Sektor Moneter}

Sektor moneter akan dipertajam dengan memasukkan persamaan-persamaan untuk financial institutions seperti perbankan. Hal ini sangat perlu dilakukan, sehingga akan

1 Presentasi kepada the Reserves Bank of New Zealand dan diskusi dengan tim modelling FPS model dilakukan pada tanggal 23 sd 27 Oktober 2000, sementara itu presentasi di Keio University dilakukan pada tanggal 3 Desember 2000. 
diperoleh jalur mekanisme transmisi terutama untuk proses pembentukan suku bunga dan kredit secara lebih akurat. Secara struktur, hal ini berarti merumuskan secara eksplisit $o b$ jective function dari sistem perbankan dan menurunkan persamaan-persamaan untuk suku bunga simpanan, suku bunga kredit dan volume kredit yang optimal melalui perhitungan optimisasi.

Penyempurnaan persamaan inflasi akan sangat terkait dengan penyempurnaan struktur sektor produksi, terutama sektor produksi non-tradables. Memasukkan variabel output gap ke dalam persamaan inflasi akan mempertajam kemampuan model dalam menangkap tekanan inflasi yang muncul, baik dari sisi permintaan maupun dari sisi penawaran.

Penyempurnaan persamaan suku bunga sebagai suatu reaction function dari otoritas moneter terhadap perkembangan ekonomi akan disempurnakan dengan memasukkan variabel expected inflation rate ke dalam persamaan Taylor rule. Expected inflation ini, sebagaimana untuk variabel expected consumption dan expected exchange rate, akan diperoleh dari Artificial Neural Network dan Genetic Algorithm.

\section{Sektor Pemerintah}

Suatu batas atas (debt ceiling) untuk hutang pemerintah (government bonds) akan dimasukkan sebagai suatu constraint dalam persamaan keuangan pemerintah dalam model. Pembatasan terhadap hutang pemerintah ini selanjutnya akan terkait dengan akan dimasukkannya suatu persamaan tax-adjustment sebagai respon pemerintah terhadap perkembangan defisit anggarannya. Defisit anggaran yang membesar akan memerlukan pendanaan yang lebih besar. Namun dengan adanya tax adjustment, pendanaan tersebut tidak akan sepenuhnya ditutup oleh peningkatan hutang (government bonds) tetapi dilakukan dengan menaikkan pendapatan pajak. Dengan kata lain, adanya debt ceiling dan tax adjustment dalam model akan memberikan suatu disciplinary devices bagi perilaku pemerintah.

\section{Sektor Eksternal}

Terkait dengan hutang luar negeri, suatu debt ceiling juga akan dimasukkan untuk membatasi meledaknya hutang luar negeri dalam model. Batas ini bisa berupa rasio maksimal external debt-to-GDP atau suatu nilai Debt Service Ratio (DSR). Penetapan debt ceiling ini selanjutnya akan dikaitkan dengan suatu mekanisme exchange rate adjustment: setiap perubahan hutang luar negeri akan menimbulkan perubahan pada real equilibrium exchange rate (depresiasi atau apresiasi) atau yang lebih dikenal sebagai fundamental equilibrium exchange rate (FEER)

Lebih jauh lagi, nilai FEER dimaksud akan merupakan resultante dari perubahan posisi hutang luar negeri dalam rangka membiayai current account deficits dan perubahan 
posisi defisit anggaran pemerintah. Dengan kata lain, nilai FEER mencerminkan suatu nilai tukar equilibrium yang diperlukan untuk mencapai kondisi external balance sekaligus internal balance.

Adanya variabel FEER tersebut selanjutnya akan mempertajam persamaan pembentukan nominal exchange rate di dalam model. Sehingga nilai tukar nominal tidak hanya dipengaruhi oleh perilaku para "chartists" (yang mengikuti pola perubahan nilai tukar di masa lalu), tetapi juga oleh perilaku para "fundamentalist traders" (yang memperhatikan fundamental perekonomian seperti budget deficits dan current account deficits).

\section{Penutup}

Secara umum dapatlah dikatakan bahwa penyusunan prototipe awal GEMBI, yang dimulai sejak awal Juni 2000, secara struktural telah meliputi aspek-aspek penting perekonomian, seperti sektor produksi, sektor moneter, sektor pemerintah dan sektor eksternal. Hasil sementara yang disajikan kiranya dapat memberi gambaran tentang manfaat apa yang akan diperoleh dari kehadiran GEMBI untuk melengkapi hasil berbagai model ekonomi yang telah ada.

Meskipun demikian disadari oleh Tim GEMBI bahwa proses untuk memperoleh suatu model GEMBI yang paripurna masihlah panjang. Penyempurnaan demi penyempurnaan untuk setiap bagian model, bahkan bagian yang terkecil, masih akan terus dilakukan dengan arah sebagaimana telah dijelaskan dalam bab VI terdahulu. Untuk itu mutlak diperlukan komitmen dan dukungan dari semua lapisan di DKM dalam setiap kegiatan Tim GEMBI dalam proses penyusunan dan pengembangan-pengembangan model lebih lanjut, sehingga diperoleh model GEMBI dalam bentuk sebagaimana yang diharapkan.

"All models are wrong. But some are useful"

(George Box)

\section{REFERENSI}

1. Agenor, Pierre dan Peter Montiel (2000), "Development Macroeconomics", second edition, Princeton, N.J. Princeton University Press.

2. Den Haan.W. dan A.Marcet (1990), "Solving the Stochastic Growth Model by Parameterizing Expectations", Journal of Business and Economics Statistics 8,p.31-34. 
3. Den Haan.W. \& A.Marcet (1994), "Accuracy in Simulations", Review of Economic Studies 61,p.3-17.

4. Diebold, Francis X., "The Past, Present, and Future of Macroeconomic Forecasting", University of Pennsylvania and NBER, October 22, 1997 in Journal of Economics Perspective (1998) 12: 175-192.

5. Drew, Aaron and Ben Hunt, "The Forecasting and Policy System: Preparing Economic Projections", the Reserves Bank of New Zealand research paper.

6. Drew, Aaron and Ben Hunt, "The Forecasting and Policy System: Stochastic Simulations of the core model", the Reserves Bank of new Zealand research paper.

7. Duffy, John dan Paul D.McNelis (2000), "Approximating and Simulating the Stochastic Growth Model: Parameterized Expectations, Neural Networks and the Genetic Algorithm".Journal of Economic Dynamics and Control,akan datang. Website: www.georgetown.edu/mcnelis.

8. Kydland, Finn E. and Edward C. Prescott, "The Computational Experiment: An Econometric Tool", Federal Reserves Bank of Minneapolis, Research Department Staff Report 178, August 1994.

9. Marcet, A.(1988), "Solving Nonlinear Models by Parameterizing Expectations", Working Paper, Graduate School of Industrial Administration, Carnegie Mellon University.

10. MATLAB, The Language of Technical Computing, v.5.3.11. dari The Math Works Inc.

11. McCallum, B., "Recent Developments in the Analysis of Monetary Policy Rules", Federal Reserves Bank of St.Louis Review, November/December 1999.

12. McNelis, Paul D., "Computational Macrodynamics for Emerging Market Economies", Department of Economics, Georgetown University, Washington DC, August 2000.

13. McNelis, Paul D.,"Inflation Targeting in Emerging Market Economies: A General Equilibrium Model for Bank Indonesia", Department of Economics, Georgetown University, Washington DC, August 2000.

14. Mendoza, Enrique G (1995), "The Terms of Trade, the Real Exchange Rate, and Economic Fluctuations", International Economic Review 36: 101-137.

15. Neural Networks Toolbox For Use with MATLAB, The Math Works Inc.

16. Tim Gembi, “Gembi v.0.0: Catatan Teknis", 29 Juni 2000, Bagian Studi Ekonomi Makro.

17. Sawyer, John A., "Macroeconomic Theory: Keynesian and New Walrasian Models", University of Pennsylvania Press, Philadelphia, 1989.

18. Sims, Christopher (2000), "Solving Linear Rational Expectations Models", Manuscript, De partment of Economics, Princeton University.

19. Tim Gembi,"Baby Gembi: A First Cut", Mei 2000, Bagian Studi Ekonomi Makro.

20. Tim Gembi, "Baby Gembi: A Simple Structure”, Mei 2000, Bagian Studi Ekonomi Makro. 